\title{
CMC
}

OCCASIONAL PAPERS

\section{Cooperative Monitoring for Confidence Building. A Case Study of the Sino-Indian Border Areas}

Waheguru Pal Singh Sidhu

Security Analyst

New Delhi India

Jing-Dong Yuan

Postdoctoral Fellow, East Asia Nonproliferation Project

Center for'Nonproliferation Studies

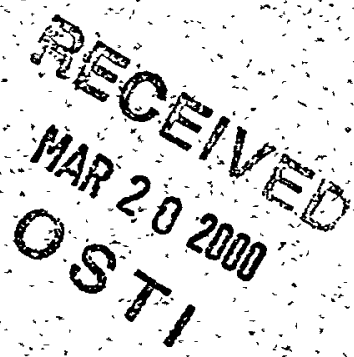

Monterey Institute of International Studiês

Monterey, Cálifornia, USA 
Issued by Sandia Natonal Laboratories operated for the United Statés Department of Energy by Sandia Corporation.

NOTICE: This report was prepared as an account of work sponsored by an agency of the United States Government Neither the United States Government nor any a gency thereot nor any of their employees, nor any of their contractors, subcontractors, or their employees, makes any warranty express or implied, or assumes any legal liability or responsibility for the accuracy completeness, or usefulness of any information apparatús product, or process disclosed, or represents that its use would not infringe privately owned rights Beference herén to any specific commercial product, prócess, or service by trade name, trademark manufacturer, or otherwise, does not hecessarily constitute or imply its endorsement recommendation or favoring by the United States Government, any agency thereof, or any of their contractors or subcontractors. The views and opinions expressed herein do not necessarily state of reflect those of the United States Government any agency thereof, or any of their contractors.

Printed th the United States of America This reporthas been repróduced directly from the best available copy.

Ávailable to DOE and DOE contractors from Office of Scientific and Technical Information P.O Box 62

Oak Ridğe $\mathrm{TN}-3783$

Price s available from ( 615$)$ 576-8401 FT $626-8401$

Available to the public from

National Techinical Information Service

US. Department of Commerce

5285 Port Royal Rd.

Springfield VA 22161

NTIS price codes

Printed Copy: AO 3

Microfiche Copy AOT 


\section{DISCLAIMER}

Portions of this document may be illegible in electronic image products. Images are produced from the best available original document. 
SAND 98-0505/13

Unlimited Release

August 1999

\section{Cooperative Monitoring for Confidence Building: \\ A Case Study \\ of the Sino-Indian Border Areas}

Waheguru Pal Singh Sidhu

Security Analyst

New Delhi, India

and

Jing-Dong Yuan

Postdoctoral Fellow, East Asia Nonproliferation Project

Center for Nonproliferation Studies

Monterey Institute of International Studies

Monterey, California, USA

Cooperative Monitoring Center Occasional Paper/13

11. Sandia National Laboratories

Sandia is a multiprogram laboratory operated by Sandia Corporation, a Lockheed Martin Company, for the United States Department of Energy under contract DE-AC04-94AL85000. 
The Cooperative Monitoring Center (CMC) at Sandia National Laboratories assists political and technical experts from around the world to acquire the technology-based tools they need to assess, design, analyze, and implement nonproliferation, arms control, and other cooperative security measures. As part of its mission, the CMC sponsors research on cooperative security and the role of technology. Reports of that work are provided through the Occasional Papers series. Research is conducted by Sandia staff as well as visiting scholars. The CMC visiting scholars program is administered by the Institute for Public Policy at the University of New Mexico. For additional information on the programs of the CMC, visit the CMC home page on the World Wide Web at <http://www.cmc.sandia.gov> or write to:

Cooperative Monitoring Center

Sandia National Laboratories

P.O. Box 5800

Albuquerque, NM 87185-1373

For specific information on this report contact:

Kent L. Biringer or John Olsen at the above address.

This report was prepared by Sandia National Laboratories Albuquerque, NM 87185 and Livermore, CA 94550 


\title{
Cooperative Monitoring for Confidence Building: A Case Study of the Sino-Indian Border Areas
}

\begin{abstract}
This occasional paper identifies applicable cooperative monitoring techniques and develops models for possible application in the context of the border between China and India. The 1993 and 1996 Sino-Indian agreements on maintaining peace and tranquility along the Line of Actual Control (LAC) and establishing certain confidence building measures (CBMs), including force reductions and limitation on military exercises along their common border, are used to examine the application of technically based cooperative monitoring in both strengthening the existing terms of the agreements and also enhancing trust. The paper also aims to further our understanding of how and under what conditions technology-based tools can assist in implementing existing agreements on arms control and confidence building. The authors explore how cooperative monitoring techniques can facilitate effective implementation of arms control agreements and CBMs between states and contribute to greater security and stability in bilateral, regional, and global contexts.
\end{abstract}




\section{Acronyms}

$\begin{array}{ll}\text { CBMs } & \text { Confidence-building measures } \\ \text { CFE } & \text { Conventional Forces in Europe } \\ \text { CMC } & \text { Cooperative Monitoring Center } \\ \text { CSBM } & \text { Confidence-and-security-building measure } \\ \text { DG } & \text { Director General } \\ \text { DMZ } & \text { Demilitarized zone } \\ \text { FEER } & \text { Far Eastern Economic Review } \\ \text { JWG } & \text { Joint Working Group } \\ \text { LAC } & \text { Line of Actual Control } \\ \text { NEFA } & \text { North East Frontier Agency } \\ \text { OSI } & \text { On-site inspection } \\ \text { PLA } & \text { People's Liberation Army } \\ \text { PRC } & \text { People's Republic of China }\end{array}$




\section{Contents}

EXECUTIVE SUMMARY 9

1. INTRODUCTION. 11

2. PERSPECTIVES, PROCESS, AND AGREEMENTS 12

2.1 Sino-INDIAN RELATIONS, 1979-1999: PROGRESS AND PROBLEMS. 13

2.2 CONFIDENCE BUILDING AND THE 1993 AND 1996 CBM AGREEMENTS 16

3. CONFIDENCE BUILDING IN A REGIONAL CONTEXT:

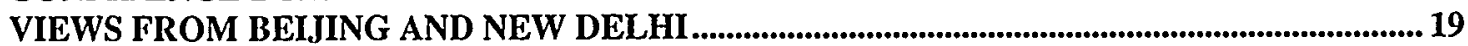

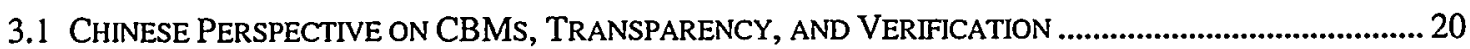

3.2 INDIAN PERSPECTIVE ON CBMS, TRANSPARENCY, AND VERIFICATION............................................. 21

4. THREE MODELS OF COOPERATIVE MONITORING ......................................................................2 24

4.1 SALIENT PROVISIONS OF THE 1993 AND 1996 SINO-INDIAN AGREEMENTS ..........................................2 24

4.2 AREAS OF MONITORING: STRATEGIC PASSES AND LoCATIONS WITH HISTORIES OF CONFLICT .......... 24

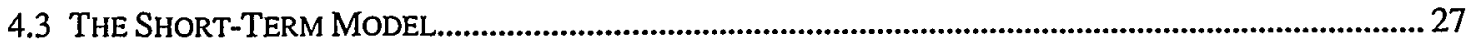

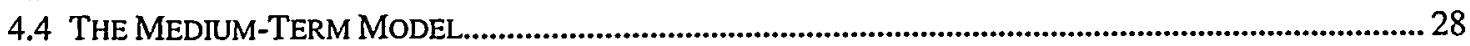

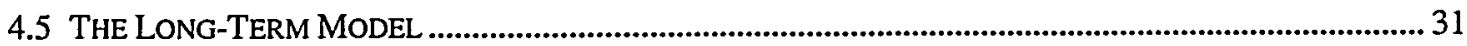

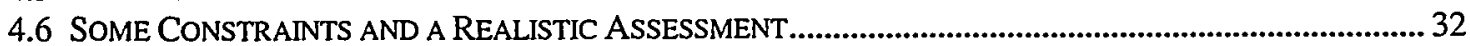

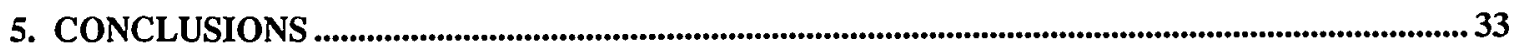

APPENDIX A: 1993 CBM AGREEMENT ON PEACE AND TRANQUILITY ................................. 35

APPENDIX B: 1996 AGREEMENT ON MILITARY CBMS...................................................................... 37

APPENDIX C: CHRONOLOGY OF SINO-INDIAN RELATIONS, 1947-1999..................................... 41

APPENDIX D: SINO-INDIAN HIGH-LEVEL EXCHANGE VISITS, 1979-1999................................. 44

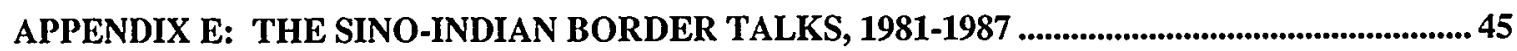

APPENDIX F: SINO-INDIAN JOINT WORKING GROUP (JWG) MEETINGS, 1989-1999 ......... 46

APPENDIX G: SELECTED GROUND SENSORS FOR MONITORING ...........................................4 47

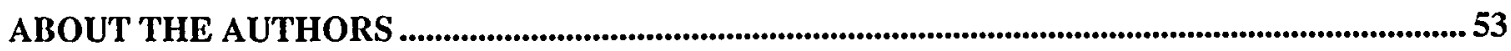

Figures

FIGURE 1. SINO-INDIAN BORDER AREAS...................................................................................... 13

FIGURE 2. SPOT IMAGE OF SPANGGUR LAKE REGION, WITH INSET OF SPANGGUR GAP................................................................................... 25

FIGURE 3. SIMULATED DEMONSTRATION OF SENSOR DEPLOYMENT AND ACTIVATION IN THE SPANGGUR GAP. 


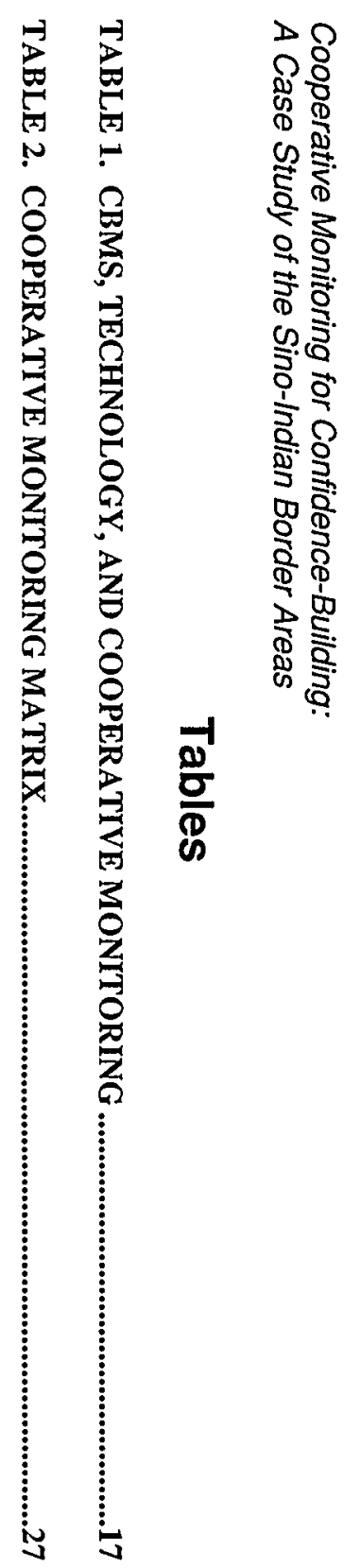




\section{Cooperative Monitoring for Confidence-Building: A Case Study of the Sino-Indian Border Areas}

\section{Executive Summary}

China and India share one of the longest undemarcated and disputed borders in the world. The two countries fought a brief but bitter border war in 1962. Since the late 1970s, Beijing and New Delhi have embarked on a process of confidence building and sought to work out a mutually acceptable solution to their border disputes. The process consisted of three distinct yet integrated levels of activities: 1) summit meetings between the heads of states of the two governments; 2) regular ministerial visits, including exchanges between the two militaries; and 3) border talks (1981-87) and the Joint Working Group meetings (1989-present). In 1993 and 1996, China and India signed two agreements to maintain peace and tranquility and on confidence building in the military field along the line of actual control (LAC) and in the border areas. Despite the setback in the wake of the May 1998 nuclear tests, this confidence building process has brought bilateral relations back on track and is likely to enhance the process of normalization.

The 1993 and 1996 agreements contain numerous declaratory, information-exchanging, and constraining provisions. The scope and limitation of the two documents to some extent reflect the attitudes of China and India to confidence-building measures, military transparency, and verification procedures. Nevertheless, the two documents contain specific provisions that lend themselves to the possibility of cooperative monitoring, including limitation on the scale of military exercises, no-fly zones for military aircraft, limitation and reduction of the size of military forces and certain equipment along the LAC, and notification and exchange of information on natural disasters and diseases.

Cooperative monitoring proceeds from the identification of verifiable provisions of arms control and confidence building agreements to the selection of both the available and appropriate technology-based tools and potential locations for their implementation. While designing specific monitoring models, their political, technical, and economic feasibility should also be taken into account.

Based on these principles, this study develops three models for cooperative monitoring. The short-term model begins with the existing flag meetings between local commanders and seeks to build upon it by expanding the interaction between troops and the installation of regular and reliable communications. In addition, shared collection and dissemination of weather and disease data can also provide opportunities for cooperation in disaster relief and disease control in the short term. 
The medium-term model requires a higher level of cooperative monitoring. In particular, this model would help increase confidence on both sides by providing reassuring information on military exercises, flight of military aircraft, disengagement from forward posts, and other significant military movements. Technology is critical: both aerial surveillance (either through satellite imaging or an "open skies" regime), and early warning (through the installation of ground sensors in strategic passes) can play an important role. A simulation model using the "Simtool" program and satellite-generated maps of the Spanggur Gap illustrates the potential and practical utility of ground sensors.

The long-term model would involve the most intrusive form of cooperative monitoring. Should the political will exist, this model envisions application of ground sensors, aerial surveillance, and limited on-site inspections to jointly monitor selected garrisons. The two agreements call for the reduction of troops and limitation of certain military equipment. These require detection of the entry and existence of forces and equipment in compliance with treaty provisions and hence the designing of specific, mutually acceptable monitoring that can detect movement of troops or equipment.

Certain political, economic, and technological constraints exist. The three models suggest that cooperative monitoring should be undertaken from the relatively easy, informationexchange CBMs, moving gradually toward more stringent verification as the two sides build trust in each other and gain confidence in understanding and applying technology-based tools. Technology can both consume and save resources. Given the length of the Sino-Indian LAC and the geological characteristics, the cost and selection of proper equipment would be very important considerations in designing and implementing cooperative monitoring models. 


\section{Cooperative Monitoring for Confidence-Building: A Case Study of the Sino-Indian Border Areas}

\section{Introduction}

The contribution of cooperative monitoring to effective implementation of arms control, non-proliferation, and confidence-building agreements has been of increasing interest to both policy makers and security analysts. Cooperative monitoring, which facilitates the acquisition, processing, analysis, and sharing of information and data by using commercially available technologies, is becoming a vital component of security building in bilateral, regional, and global contexts. Several studies have assessed the utility of cooperative monitoring in areas as diverse as Europe, the Middle East, and Northeast Asia and in agreements as distinct as the Conventional Forces in Europe (CFE) Treaty and military disengagement in the Sinai Peninsula. ${ }^{1}$ Cooperative monitoring, by its very nature of making information available to all parties, has great potential for building trust and confidence between states.

This occasional paper examines the potential role cooperative monitoring can play in implementing the two confidence-building measure (CBM) agreements signed by China and India in 1993 and 1996. Specifically, the study aims to achieve the following five objectives:

- First, to provide a brief account of Sino-Indian relations over the last twenty years (19791999), identify major disputes, record the progress made through the confidence-building process, and note the remaining obstacles to a better bilateral relationship.

- Second, to analyze the two agreements, examine the key provisions and assess their verifiability, and hence the likelihood of enforcement.

- Third, to review and compare Chinese and Indian perspectives on confidence building, military transparency, and verification. This would help to explain not only the limited nature of the two Sino-Indian CBM agreements but also to anticipate some obstacles in their implementation.

- Fourth, to identify the technologies that are available and appropriate in designing verification models and certain provisions in the agreements that lend themselves to joint verification and cooperative monitoring by both China and India.

- Finally, based on the provisions of the agreements, the appropriate technology, and possible locations for their implementation, three specific cooperative monitoring models will be presented.

Given that cooperative monitoring both as a concept and practice is something new to China and India, we hope our findings can demonstrate the positive role of cooperative

\footnotetext{
${ }^{1}$ Refer to the CMC Web Page at http://www.cmc.sandia.gov for a variety of papers and cooperative monitoring information resources.
} 
monitoring in dispelling some concerns and misperceptions between countries. In doing so, we hope to present a stronger case for the two countries to open up new avenues of cooperation and confidence building.

\section{Perspectives, Process, and Agreements}

China and India share one of the longest undemarcated and disputed borders in the world (see Figure 1). No treaty has ever formally delimited the disputed boundary, ${ }^{2}$ which affects over $125,000 \mathrm{~km}^{2}$. The border issue was the primary cause for the Sino-Indian confrontation in the late 1950 s and led to the brief but bitter border war fought in $1962 .{ }^{3}$ Since then India and China have clashed several times in the 1970s and 1980s, with the standoff at Sumdorong Chu in the eastern sector in 1986-87 being the most serious of them. Even today the border issue continues to cast a shadow over bilateral relations. Since the late 1970s, however, Beijing and New Delhi have sought to resolve the issue through border negotiations and confidence-building measures (CBMs). In 1993 and 1996, China and India signed two important agreements to maintain peace and tranquillity and reduce tensions along the Line of Actual Control (LAC), including force reductions and limitations on military activities (see Appendices $A$ and $B$ for full texts of the agreements). However, long-term peace and stability in bilateral relations require fundamental changes in Beijing and New Delhi's perceptions of security, regional rivalry, and the eventual resolution of territorial disputes. ${ }^{4}$

\footnotetext{
${ }^{2}$ However, according to Chinese scholars, a boundary line of actual control has existed between the two countries that formed over time on the basis of administrative jurisdiction. See, for example, Chen Tiqiang, "Zhongyin bian jie wenti de falu fangmian [Legal Aspects of the Sino-Indian Boundary Problems]," Guoji wenti yanjiu [International Studies], No. 1 (January 1982), pp. 11-42; Jing Hui, "Zhongyin dongduan bianjie zhenxiang [The Truth about the Eastern Sector of Sino-Indian Boundary]," Guoji wenti yanjiu [International Studies], No. 1 (January 1988), pp. 6-12, 30; idem, "Youguan zhongyin bianjie zhengduan de yixie qingkuang he beijing [Some Facts about the Background of the Sino-Indian Boundary Dispute]," Guoji wenti yanjiu [International Studies], No. 2 (April 1986), pp. 1-8; and Xuecheng Liu, The Sino-Indian Border Dispute and Sino-Indian Relations (Lanham, MD: University Press of America, 1994), p. 1; p. 47.

${ }^{3}$ There are several excellent studies that examine the history and origins of the Sino-Indian border disputes that lead up to the 1962 war. See, for instance, Gyaneshwar Chaturvedi, India-China Relations: 1947 to Present (Agra: M G Publishers, 1991); W.F. Van Eekelen, Indian Foreign Policy and the Border Dispute with China (The Hague: Martinus Nijhoff, 1964); Steven A. Hoffmann, India and the China Crisis (Berkeley: University of California Press, 1990); Alastair Lamb, The China-India Border: The Origins of the Disputed Boundaries (London: Praeger, 1964) and Asian Frontiers: Studies in a Continuing Problem, (New York: Praeger, 1968); Neville Maxwell, India's China War (London: Jonathan Cape Limited, 1970); Parshotam Mehra, Negotiating with the Chinese 18461987: Problems and Perspectives, (New Delhi: Reliance Publishing House, 1989); Mohan Ram, Politics of SinoIndian Confrontation, (Delhi: Vikas, 1973); Sahdev Vohra, The Northern Frontier of India - The Border Dispute with China (New Delhi: Intellectual Publishing House, 1993); and Dorothy Woodman, Himalayan Frontiers: A Political View of the British, Chinese, Indian and Russian Rivalries (New York: Praeger, 1969).

${ }^{4}$ J. Mohan Malik, "China-India Relations in the Post-Soviet Era: The Continuing Rivalry," The China Quarterly 142 (June 1995), pp. 317-353; Wang Hongyu, "Sino-Indian Relations: Present and Future," Asian Survey XXXV:6 (June 1995), pp. 546-554; Damon Bristow, "Mutual mistrust still hampering Sino-Indian rapproachement," Jane's Intelligence Review (August 1997), pp. 368-371.
} 


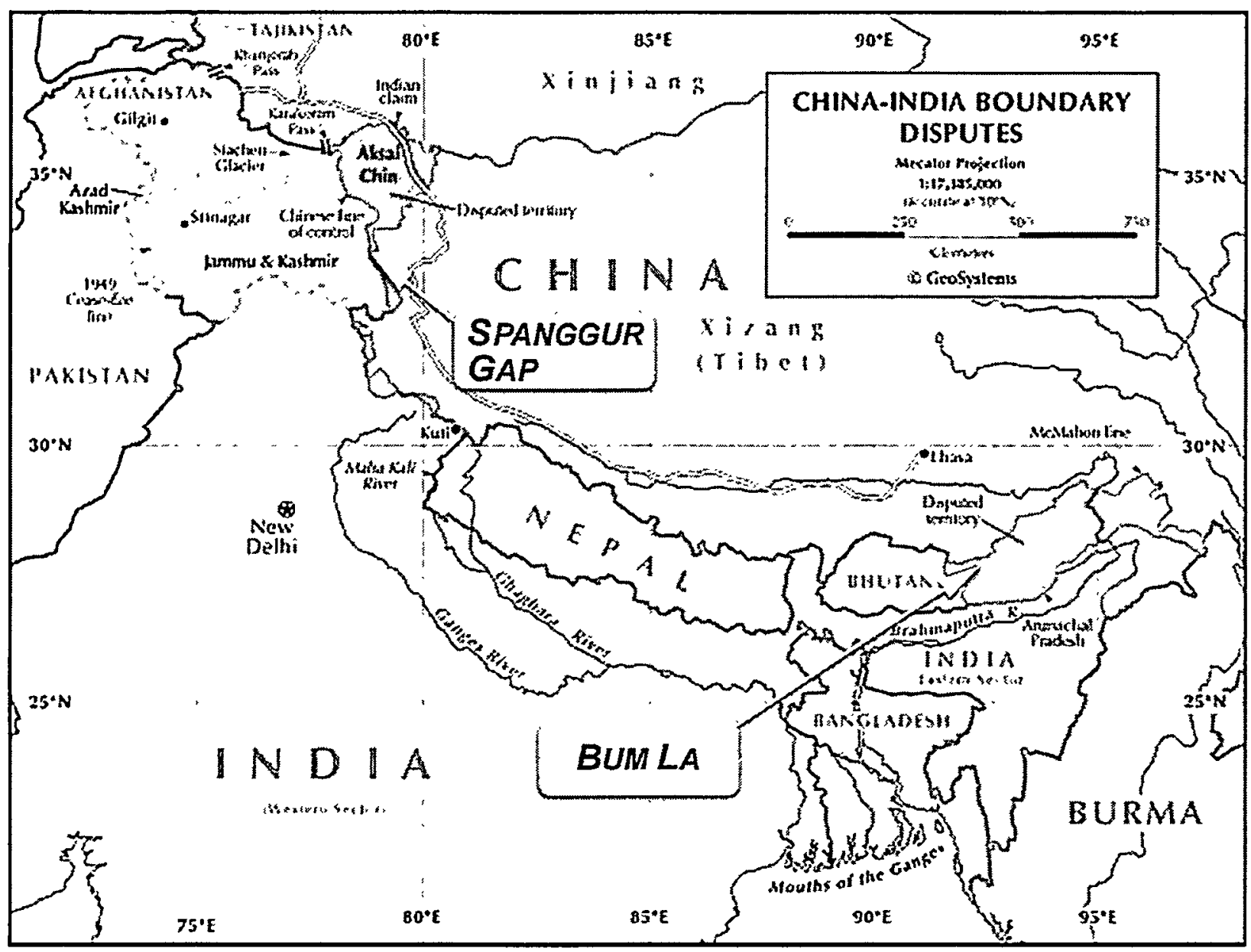

Figure 1. Sino-Indian Border Areas.

\subsection{Sino-Indian Relations, 1979-1999: Progress and Problems}

The 1962 war between China and India had left a deep scar on bilateral relations. ${ }^{5}$ It was not until 1976 that the two countries again exchanged ambassadors. In February 1979, Indian Foreign Minister Atal Bihari Vajpayee visited China. Slow and tentative steps were taken to reduce tension and the two countries began to explore ways to resolve their territorial disputes. Over the next two decades, the process of Sino-Indian confidence building evolved slowly (see Appendix $\mathrm{C}$ for a chronology of Sino-Indian relations and the process of confidence building over the past twenty years).

This process consisted of the following three distinct yet reinforcing levels of activities:

- summit meetings between the heads of states and governments

- regular exchange visits between high-ranking officials including the military, especially at the ministerial level (see Appendix D)

\footnotetext{
${ }^{5}$ For different views of the war, see Maxwell, India's China War, and D.K. Palit, War in the High Himalayas: Indian Army in Crisis, 1962 (South Asian Books: 1992).
} 
- slow process of institutionalizing a series of CBMs over a period of twenty years (1979-1999).

This three-pronged process continues even today.

For analytic purposes, the last process can be divided into three distinct regimes. The first consisted of the Sino-Indian border talks. Eight rounds were held between 1981 and 1987 (see Appendix E). The second regime is the Joint Working Group (JWG) and its attached diplomatic and military experts group. Between 1989 and 1999 eleven JWG meetings have been held. Finally, the concrete result of this process was embodied in the agreements: the Agreement on Maintaining Peace and Tranquillity in the Border Areas along the Line of Actual Control in September 1993, and the Agreement on Confidence-Building Measures in the Military Field Along the Line of Actual Control in the India-China Border in November 1996. Thus while the first two processes paved the way for improved relations, it was the third process that not only institutionalized the relationship but also proved that the process of normalization was bearing results. ${ }^{6}$

Over the last twenty years, the process of Sino-Indian normalization and confidence building has yielded significant results. ${ }^{7}$ These include:

1. resumption and regularization of high-level exchange visits between government and military leaders to facilitate dialogues and consultation between the two countries on bilateral, regional, and global issues;

2. expanded contacts and cooperation in a broad range of areas such as trade, education, and cultural exchanges;

3. serious efforts at bridging the gap between Beijing and New Delhi regarding border negotiations; and

4. steady and gradual progress in military CBMs leading to the 1993 and 1996 agreements.

\footnotetext{
${ }^{6}$ Dilip Bobb, "Rajiv Gandhi in China: Breaching the Wall," India Today, January 15, 1989, pp. 14-21; Robert Delfs and Rita Manchanda, "Return to realism," Far Eastern Economic Review (FEER), January 5, 1989, pp. 10-1 1; Lincoln Kaye, "Bordering on Peace," FEER, September 16, 1993, p. 13; Shekhar Gupta and Sudeep Chakravarti, "Sino-Indian Relations: Vital Breakthrough," India Today, September 30, 1993, p. 23; Rahul Bedi, "India, China set to ease tension," Jane's Defence Weekly, December 11, 1996, p. 14; Dipankar Bannerjee, "Upbeat About SinoIndian Ties," Trends, December 28-29, 1996, p. iv.

${ }^{7}$ Rosemary Foot, "Chinese-Indian relations and the process of building confidence: Implications for the AsiaPacific," The Pacific Review 9:1 (1996), pp. 58-76; Kanti Bajpai and Bonnie L. Coe, "Confidence Building Between India and China," in Michael Krepon and Amit Sevak, eds., Crisis Prevention, Confidence Building, and Reconciliation in South Asia (New York: St. Martin's Press, 1995), pp. 199-226; Ye Zhengiia, "Sino-Indian Friendship and Cooperation Contribute to Peace and Development in Asia and the World At Large," Studia Diplomatica XLIX:4-5 (1996), pp. 111-120; and Sony Devabhaktuni, Matthew C.J. Rudolph, and Amit Sevak, "Key Developments in the Sino-Indian CBM Process," in Michael Krepon et al., eds., A Handbook of ConfidenceBuilding Measures for Regional Security, $3^{\text {rd }}$ Edition (Washington, DC: The Stimson Center, March 1998), pp. $201-$ 204.
} 
The bilateral relationship has not always been smooth sailing. Several incidents occurred during this period, setting back the normalization process and casting serious shadows on future direction. The first was India's upgrading of the North East Frontier Agency (NEFA) to the state of Arunachal Pradesh in December 1986. This incurred strong protest from Beijing, which charged that India "seriously violated" China's territorial integrity and sovereignty. ${ }^{8}$ The second was the 1986-87 border standoff in Sumdorong Chu in the eastern sector, where both sides deployed large number of troops, which almost escalated into open conflict. ${ }^{9}$ China's own missile program and its suspected supply of nuclear weapon and missile-related technology to Pakistan as well as other countries in the region was another bone of contention between New Delhi and Beijing. ${ }^{10}$

Finally, India's nuclear tests in May 1998 caused another major setback in bilateral relations. ${ }^{11}$ China reacted strongly and canceled the scheduled November 1998 JWG meeting in Beijing. ${ }^{12}$ While the events surrounding the May 1998 tests were the immediate causes, the roots of animosity go much deeper: regional rivalry, Tibet, the India-China-Pakistan triangle, and domestic politics. ${ }^{13}$ Recent developments (since January 1999) have pointed to an encouraging return to "normalcy". There have been exchange visits and dialogues between the two countries at the Track II level; Indian and Chinese officials held bilateral consultation at the Director General (DG) level this past February; ${ }^{14}$ and the eleventh round of the JWG meeting was held on April 2627, 1999, in Beijing. ${ }^{15}$ This was followed by Indian Foreign Minister Jaswant Singh's visit to

\footnotetext{
${ }^{8}$ Mohan Ram, "Bluster on the border," FEER, January 1, 1987, pp. 22-23; Liu, The Sino-Indian Border Dispute, p. 142.

${ }^{9}$ For background and analysis, see Robert G. Sutter, China-India Border Friction: Background Information and Possible Implications, CRS Report for Congress 87-514F (June 19, 1987). See also, Salamat Ali, "Tension on the border," FEER, May 7, 1987, pp. 33-35; David Bonavia, "Troubled frontiers," FEER, September 4, 1986, pp. 1415; "Eye-witness in Tibet," FEER, June 4, 1987, p. 46; Salamat Ali, "China ups the ante," FEER, May 21, 1987, p. 40.
}

${ }^{10}$ See R. Jeffrey Smith and David B. Ottaway, "Spy Photo Suggests China Missile Trade," Washington Post, July 3, 1995; Smith, "China Linked to Pakistani Missile Plant," Washington Post, August 23, 1996; Douglas Waller, "The Secret Missile Deal," Time, June 30, 1997, p. 58; and "Fernandes Sees No Threat From Ghauri," The Hindu, April 10, 1998. See also "Overview" in Report of the Select Committee on U.S. National Security and Military/Commercial Concerns with the People's Republic of China (Washington, DC: U.S. Government Printing Office, May 1999), pp. xxxvi-vii.

"John F. Burns, "India's New Defense Chief Sees Chinese Military Threat," New York Times, May 5, 1998, p. A6; Manoj Joshi, "The Big Chill," India Today, August 24, 1998, http://www.india-today. com/itoday/ 24081998/diplo.html.

12 Rahul Bedi, "New tensions halt India-China talks," Jane's Defence Review, December 23, 1998, p. 16.

${ }^{13}$ See, for example, J. Mohan Malik, "India Goes Nuclear: Rationale, Benefits, Costs and Implications," Contemporary Southeast Asia 20:2 (August 1998), pp. 191-215, and "The India-China Divide," The Hindustan Times, May 24, 1999, http://www.hindustantimes.com/nonfram/240599/detOPI01.htm; Sujit Dutta, "China's Emerging Power and Military Role: Implications for South Asia," in Jonathan D. Pollack and Richard Yang, eds., Under the China Shadow (Santa Monica, Calif.: RAND, 1998), pp. 91-114; Timothy Mapes, "Nervous Neighbours," FEER, December 12, 1996, pp. 16-17.

14 “Sino-Indian talks positive: MEA," The Hindustan Times, March 1, 1999, http://www.hindustantimes. com/nonfram/ 010399/detFOR05.htm.

15 "Indo-China Talks 'Friendly'," Inside China Today, May 2, 1999, www.insidechina.com/china/news/ 15.html. 
Beijing on June 14-16, 1994. During the visit, both sides agreed to hold talks on demarcating the LAC. ${ }^{16}$

\subsection{Confidence Building and the 1993 and 1996 CBM Agreements}

The JWG meetings have played an instrumental role in developing and implementing CBMs in the military field (see Appendix $\mathrm{F}$ for a list of the meetings and major developments), which in turn are codified in the 1993 and 1996 agreements. Despite ups and downs, progress has been made in several important areas. First is the establishment of the Military and Diplomatic Experts Group within JWG. The second has been the initiation of regular flag meetings between local commanders where the two sides have agreed that military personnel would meet twice a year (June and October) at Bum La and Dichu in the eastern sector, Lipulekh near Pithoragarh in the middle sector, and Spanggur Gap near Chushul in the western area. ${ }^{17}$ In addition, direct telephone links between local commanders have been proposed to facilitate better communication. ${ }^{18}$ Third, through the JWG process, concerns and disputes can be raised, clarified, and even resolved.

Additional measures that would ensure greater transparency in the location of forward posts and military activities along the LAC have been adopted. These include prior notification of military exercises, prevention of air intrusion, and the agreement to pull back troops from four posts within 50-100 yards of each other in the Sumdorong Chu Valley (Wangdung area). ${ }^{19}$ All in all, the JWG meetings have served important purposes as the contact points for candid discussions, as well as for developing specific CBMs to enhance the overall peace and tranquillity along the LAC. $^{20}$

The 1993 and 1996 Sino-Indian CBM agreements can be seen as the crowning achievements in the long process of normalizing bilateral relations. The major features of the two Sino-Indian agreements, divided into declarative, information-exchange, and constraining CBMs, are listed below.

\footnotetext{
${ }^{16}$ Reuters, June 18, 1999, http://www.insidechina.com/news.php3?id

${ }^{17}$ Swaran Singh, "Sino-Indian CBMs: Problems and Prospects," Strategic Analysis XX:4 (July 1997), pp. 543-559; Hua Han, "Sino-Indian relations and nuclear arms control," in Eric Arnett, ed., Nuclear Weapons and Arms Control in South Asia after the Test Ban (Oxford University Press for SIPRI, 1998), p. 44; Manoj Joshi, "Shy hands across the Himalayas," Asia-Pacific Defense Reporter (April-May 1993), p. 15.

${ }^{18}$ Foot, "Chinese-Indian relations," pp. 63-65; Prakash, "The Sixth Meeting of the Indo-China Joint Working Group on the Boundary Question," China Report 30:1 (January-March 1994), p. 92; Zheng Ruixiang, "Xin xingshixia de zhongyin guanxi [Sino-Indian Relations under New Circumstances]," Guoji wenti yanjiu [International Studies], No. 4 (October 1993), p. 6. See also, Policy Research Office, the Foreign Ministry of the People's Republic of China, Zhongguo waijiao [Chinese Diplomacy] (Beijing: Shijie zhishi chubanshe, 1996), p. 100; Fang Jinying, "China and Confidence Building Measures," Pacific Research 7:3 (August 1994), p. 24.

${ }^{19}$ Swaran Singh, "Sino-Indian CBMs: Problems and Prospects," Strategic Analysis XX: 4 (July 1997), http://www.idsa-india.org/an-jul-4.html.

${ }^{20}$ Mansingh, "India-China Relations," pp. 291-292; Shri Prakash, "The Sixth Meeting of the Indo-China Joint Working Group," pp. 92-93.
} 


\section{Declarative Principles}

- Neither side shall use or threaten to use force against the other

- Both sides shall strictly respect and observe the LAC

- Both sides shall seek a fair, reasonable, and mutually acceptable settlement of the boundary question

- Each side will keep its military forces in the border areas along the LAC to a minimum level

\section{Information-Exchange Measures}

- Setting up of the diplomatic-military experts group to hold regular meetings on implementation

- Establishing hot lines and increasing meetings between border troop commanders and other authorities at designated points

- Exchanging information on natural disasters and diseases along the border

\section{Constraining Measures}

- Limiting the size of military forces within agreed zones along the LAC, including setting ceilings on the number of main battle tanks and infantry combat vehicles with main guns of 75 $\mathrm{mm}$ or larger, mortars with a calibre of at least $120 \mathrm{~mm}$, surface-to-air missiles and surface-tosurface missiles each side can have (the limits remain to be negotiated)

- Avoiding large-scale military exercises involving more than one division (15,000 troops) and providing prior notification to the other side on exercises involving more than one brigade (5,000 troops)

- Prohibiting combat aircraft flights within $10 \mathrm{~km}$ of the LAC without prior notification; however, unarmed transport aircraft and helicopters are permitted to fly up to the LAC

- Prohibiting firing, blasting, and hunting within $2 \mathrm{~km}$ of the LAC

- Self-restraint in situations of face-to-face confrontation

Table 1 shows the relationship between the categories of CBMs, the technology needed to implement them, and their value for cooperative monitoring. It reveals that declaratory CBMs require the least amount of technology input and cooperative monitoring to be successfully enforced. In contrast, constraining CBMs require the greatest technological input and need a high level of cooperative monitoring to be successfully implemented.

Table 1. CBMs, Technology, and Cooperative Monitoring

\begin{tabular}{|l|l|l|}
\hline \multicolumn{1}{|c|}{ Type of CBMs } & Technology Requirements & Cooperative Monitoring \\
\hline Declaratory & Not essential & Not crucial \\
\hline Information exchange & Required & Useful though not crucial \\
\hline Constraining & Essential & Crucial \\
\hline
\end{tabular}


One general observation can be made of the two agreements: the CBMs have evolved from the initial primary concerns over surprise military attacks to the current orientation toward transforming security relationships. To understand this evolution, an analysis of the nature of the two Sino-Indian CBM agreements is essential. An obvious caveat, though, is that given the early stage of implementation and the scarcity of information pertaining to the force reduction, the analysis will tend to be highly tentative. ${ }^{21}$

The two Sino-Indian agreements are limited in scope and application, declarative in large measures, and contain minimum constraining measures. Implementation and verification receive scant mention. These two documents function more as conflict avoidance measures than CBMs. Conventional CBMs, as developed in the European context, require greater political capital and entail much more stringent verification and implementation provisions. ${ }^{22}$ These limitations reflect the two countries' attitudes towards confidence building, military transparency, verification, and the specific circumstances under which negotiation took place. Indeed, the impetus for negotiating CBMs in the Sino-Indian context has been predominantly political and only secondarily military. As noted earlier, the post-1962 Indo-China border areas have remained peaceful without any formal CBMs in place. Since India and China have no immediate concerns over the other side's military intentions, confidence building in this context serves to reduce tension, enhance understanding and trust, and pave the way toward eventual resolution of territorial disputes between the two countries. ${ }^{23}$ This explains why the two agreements are long in declaratory statements and short in verifiable provisions. ${ }^{24}$ This is not to belittle the importance of political goodwill behind declaratory CBMs but only to suggest that although both Beijing and New Delhi realize that verifying CBM agreements is essential for securing peace and stability, neither is willing to tread down that path at present.

The two agreements remain deficient in the key areas of specific force reduction, implementation, and verification measures for several reasons. One is the reality on the ground. On the Sino-Indian LAC, nature imposes harsh conditions that make massive, deliberate military concentration very difficult to undertake. At the same time, force reduction and redeployment

\footnotetext{
${ }^{21}$ What can be realistically achieved is an assessment of the Sino-Indian agreements against some of the major characteristics that analysts have prescribed for CBMs in the voluminous literature on the subject. See, for example, Marie-France Desjardins, Rethinking Confidence-Building Measures, Adelphi Paper 307 (London: Oxford University Press/IISS, 1996); Michael Krepon et al., eds., A Handbook of Confidence-Building Measures for Regional Security (New York: St. Martin's Press, forthcoming); James Macintosh, Confidence-Building in the Arms Control Process: A Transformation View, Arms Control and Disarmament Studies No. 2 (Ottawa: Department of Foreign Affairs and International Trade, 1996).

${ }^{22}$ On this point, see Michael Krepon, "Conflict Avoidance, Confidence-Building, and Peacemaking," in Krepon, $A$ Handbook of Confidence-Building Measures for Regional Security, pp. 1-13.

${ }^{23}$ However, this may have changed in the wake of Indian nuclear testing and its continued missile developments. See Ming Zhang, China's Changing Nuclear Posture: Reactions to the South Asian Nuclear Tests (Washington, DC: Carnegie Endowment for International Peace, May 1999); M.V. Rappai, "India-China Relations and the Nuclear Realpolitik," Strategic Analysis XXIII: 1 (April 1999), pp. 15-26.

${ }^{24}$ On declaratory CBMs, see Michael Krepon, Jenny S. Drezin, and Michael Newbill, eds., Declaratory Diplomacy: Rhetorical Initiatives and Confidence Building (Washington, DC: The Stimson Center, April 1999).
} 
have already taken place over the years, making it unnecessary for China and India to go beyond principles and declarations. For instance, there have been reports that India removed 35,000 troops in the eastern sector in the early 1990s. ${ }^{25}$ Another equally credible explanation is that New Delhi and Beijing could not agree on the specific terms of CBMs, in particular those pertaining to force structure, level, and locations. For instance, India has always insisted that any force withdrawal and/or reduction along the LAC should be based on the principle of equitable rather than equal measures, given the advantages China enjoys with regard to terrain and logistics. ${ }^{26}$ Because of the disagreement (or lack of agreement), the terms of implementation and verification are equally difficult to negotiate. ${ }^{27}$ However, this does not mean that no incentive exists for New Delhi and Beijing to move forward. Perhaps the 1986-87 Sumdorong Chu crisis reiterates the importance of negotiating and implementing verifiable provisions in bilateral CBM agreements. Both Beijing and New Delhi realize that without elaborate CBMs in place, a similar crisis could recur in the future.

Before we examine the precise provisions of the two CBM agreements that might call for monitoring and verification, it would be useful to review Beijing and New Delhi's perspectives on CBMs, transparency, and verification. This enables us to understand what drives the CBM process and what could be the political and ideological hurdles in the process. It also helps to put into context the broader international, regional, bilateral, and domestic considerations behind the post-Cold War security concerns of the two countries.

\section{Confidence Building in a Regional Context: Views from Beijing and New Delhi}

The motivation for CBMs, as they evolved in the European context during the Cold War years, derived from a shared concern over unintended escalation due to the tense security environment. A key objective of first-generation CBMs was to reduce mistrust, misunderstanding, and miscalculation regarding military activities and intentions by making available relevant information to concerned parties. ${ }^{28}$ By extension, CBMs sought to improve mutual trust and gradually pave the way for arms control and disarmament. ${ }^{29}$ This was followed by the secondgeneration CBMs, which have become broader in scope and contain such provisions as mandatory on-site inspections. As they now include not only enhancing confidence but also building security,

\footnotetext{
${ }^{25}$ Manoj Joshi, "Shy hands across the Himalayas," Asia-Pacific Defense Reporter (April-May 1993), p. 15; Mansingh, "India-China Relations," p. 291.

${ }^{26}$ Shekhar Gupta, "Vital Breakthrough," India Today, September 30, 1993, p. 25.

${ }^{27}$ Damon Bristow, "Mutual mistrust still hampering Sino-Indian rapprochement," Jane's Intelligence Review (August 1997), p. 370.

${ }^{28}$ Cathleen S. Fisher, "The Preconditions of Confidence-Building: Lessons from the European Experience," in Krepon, A Handbook of Confidence-Building Measures for Regional Security, pp. 261-275.

${ }^{29}$ Rakesh Sood, "Confidence-building Measures: Regional Applications of Agreed Global Principles," in Disarmament in the Last Half Century and Its Future Prospects, Disarmament Topical Papers 21 (New York: United Nations Centre for Disarmament Affairs, 1995), pp. 133-139; Antonia Handler Chayes and Abram Chayes, "Regime Architecture: Elements and Principles," in Janne E. Nolan, ed., Global Engagement: Cooperation and Security in the $21^{\text {st }}$ Century (Washington, DC. The Brookings Institution, 1994) p. 82.
} 
they are known as confidence-and-security-building measures (CSBMs). ${ }^{30}$ Hence, confidence building is now defined as "a distinctive type of security management activity entailing the comprehensive process of exploring, negotiating, and then implementing information, interaction, and constraint measures according to predominantly co-operative practices and principles.",31

Both China and India have developed their own unique perspectives on CBMs, which reflect not only their historical, cultural, and strategic thinking, but are also their regional settings. As these perspectives were developed outside the context of East-West confrontation, they also provide an alternative to the conventional, predominantly Eurocentric CBMs purely in the Cold War setting. For instance, the European CBM model tends to be legalistic and narrower in its focus, with a special emphasis on military issues. In contrast, the "Asian" CBM model tends to be more practical and broader in scope, covering political and economic, as well as military, issues. Therefore, this perspective provides not only an alternative orientation to the subject of CBMs, but also provides a competing model for the post-Cold War world. A study of Chinese and Indian perspectives also provides some insights into the limited nature of the two bilateral CBM agreements and determines the potential role of cooperative monitoring in their implementation.

\subsection{Chinese Perspective on CBMs, Transparency, and Verification}

Chinese approaches to CBMs, military transparency, and verification demonstrate the extent to which Beijing has embraced the concept of cooperative security. There is no denying that China's attitudes to confidence building have shifted from suspicion and dismissal in the early days, to selected and guarded endorsement over the past decade. ${ }^{32}$ However, reflecting a holistic approach to security and arms control issues, China has maintained that military CBMs only form one aspect of overall inter-state relationships. In other words, attempts at military CBMs probably would not go very far if not accompanied by an overall improvement in trust and confidence in political, economic, and social spheres. ${ }^{33}$

The Chinese therefore always emphasize that CBMs should be broader in scope and not confined to the military sphere. Indeed, a more useful way of conducting confidence building is to begin with nonmilitary issues. Once confidence and trust have been established in political, diplomatic, and economic spheres, the process of confidence building then can be introduced to deal with military issues. ${ }^{34}$ Another characteristic of the Chinese approach is the advocacy for a

\footnotetext{
${ }^{30}$ Desjardins, Rethinking Confidence-Building Measures, p. 16.

${ }^{31}$ Macintosh, Confidence Building in the Arms Control Process, p. 1, emphasis added.

${ }^{32}$ Michael Krepon, ed., Chinese Perspectives on Confidence-building Measures, Report No. 23 (Washington, DC: The Stimson Center, May 1997); Liu Huaqiu, "Step-by-Step Confidence and Security Building for the Asian Region: A Chinese Perspective," in Ralph A. Cossa, ed., Asia Pacific Confidence and Security Building Measures (Washington, DC: The Center for Strategic and International Studies, 1995), pp. 119-136; Kenneth W. Allen, "China's Approach to Confidence-Building Measures," in Ranjeet K. Singh, ed., Investigating Confidence-Building Measures in the Asia-Pacific Region (Washington, DC: The Stimson Center, May 1999), pp. 1-24.

${ }^{33}$ Liu Huaqiu and Zheng Hua, "Confidence-building Measures in Asia," in Krepon, Chinese Perspectives on Confidence-building Measures, p. 1.

${ }^{34} \mathrm{Si}$ Chu, "Confidence-Building in Asia-Pacific," Beijing Review 34:9 (March 4-10, 1991), pp. 15-16.
} 
step-by-step approach. However, this general approach does not preclude the adoption of specific tactics to specific situations: with the former Soviet Union, a sector-by-sector approach was adopted; in the Sino-Indian case, however, Beijing has consistently advocated a package deal.

Military transparency, according to Chinese analysts, can only proceed step by step. There should not be a uniform standard for military transparency, as a similar degree of transparency would have different impacts on states' security. ${ }^{35}$ China, for instance, can never provide the same degree of military transparency as the United States because of its weaker military position. ${ }^{36}$ The fear is that greater transparency may reveal information about a country's military weakness, which is otherwise unavailable. The aim of increasing transparency should be to enhance security rather than undermine it. ${ }^{37}$ Transparency itself is not a panacea and should parallel other efforts that promote political trust and a peaceful environment.

The Chinese accept the principle of verification but are sensitive to its potential abuse. They suggest that any verification mechanism must be strict, effective, fair and reasonable, and provide equal rights and obligations to all parties. Fair verification should accord each party equal access to verification-related information, resources, and technology. Out of concern over potential abuse, China is strongly opposed to the use of national technical means for verification purposes. Finally, China has proposed several principles for on-site inspections. Inspections should be minimally intrusive and applied only as a last resort after all other means of verification have been exhausted. ${ }^{38}$

\subsection{Indian Perspective on CBMs, Transparency, and Verification}

Indian analysts argue that CBMs in the Asian context in general and the Indian context in particular arose out of the unique regional experience and predate Western models. ${ }^{39}$ They point to the Joint Defense Council of 1948 (set up to carry out the division of armed forces and assets between the newly independent states of India and Pakistan) and the 1972 Simla Agreement (reached after the 1971 India-Pakistan war) as well as the 1954 Sino-Indian Panchsheel Agreement and the more recent 1993 and 1996 Sino-Indian agreements as examples of CBMs. The Indian perception of CBMs is derived from its own regional experience (particularly with Pakistan and China), and hence quite distinct from the East-West definition of CBMs, which evolved during the Cold War years. ${ }^{40}$ According to Rakesh Sood, "[t]here is no global CBM

\footnotetext{
${ }^{35}$ See Allen, "China's Approach to Confidence-Building Measures," p. 10.

${ }^{36}$ Xia Liping, "The Evolution of Chinese Views Toward CBMs," in Krepon, Chinese Perspectives on Confidencebuilding Measures, p. 17.

${ }^{37}$ Luo Renshi, "On the Ways of and China's Efforts in Increasing Transparency in the Asia-Pacific Region," International Strategic Studies 4 (1995), pp. 11-12.

38 "China's position on CTBT on-site inspection," Working Paper, CD/NTB/WP.266, September 5, 1995.

${ }^{39}$ Singh, "Sino-Indian CBMs: Problems and Prospects," Strategic Analysis (July 1997), Vol. XX, No. 4, p. 543.

${ }^{40}$ On this point, see Andrew Latham, "Constructing National Security: Culture and Identity in Indian Arms control and Disarmament Practices," in Keith R. Krause, ed., Culture and Security: Multilateralism Arms Control and Security Building (London: Frank Cass, 1999), p. 150.
} 
formula which can be automatically applied in all situations... Therefore, CBM packages need to be tailored to specific situations. ${ }^{, 41}$

The bulk of India's CBM agreements with both China and Pakistan are declaratory in nature with little or no verification provisions. This is particularly true in the case of the 1988 India-Pakistan "Agreement on the Prohibition of Attack against Nuclear Facilities," where both sides are only committed to exchanging lists of nuclear sites every year on January 1. According to one commentator, "adherence to the agreement requires little more than common sense."42 Yet, despite this declaratory adherence, the non-attack agreement remains one of the cornerstones of the India-Pakistan CBM process.

Similarly, agreements that contain provisions for verification and monitoring have not been fully implemented. This is evident in the case of the 1993 and 1996 Sino-Indian CBM agreements that call for limiting troop and equipment levels. These arrangements have yet to be worked out between the two sides, although Indian officials affirmed that India is committed to eventually implementing these provisions. ${ }^{43}$

India's approach to CBMs, transparency, and verification has also evolved over time. Initially it was used by India to counter the diplomatic pressure exerted by the politically and militarily stronger United States and other Western powers. Over time, for a variety of reasons, India too began to appreciate CBMs not merely as diplomatic and political stratagems but as the means to enhance its own security vis-à-vis its neighbors. This evolution has been a slow one, in which India tentatively has signed on to bilateral agreements that would entail some elements of verification and monitoring but has not rushed to implement them. While accepting the principle of CBMs and verification, India has also stressed the need for "an asymmetry in obligations" based on the "asymmetry of threat perceptions." 44 India has been less hesitant to sign on to universally applicable global agreements (such as the Chemical Weapons Convention) even though they contain far more stringent provisions for intrusive verification. This reveals that India's approach to CBMs is not monolithic but is region and context specific.

There is a remarkable convergence between the attitudes of both India and China towards CBMs. Three key elements stand out that have important implications for implementation and verification. One is that political environments determine both the scope of CBMs and the likelihood of their effective implementation. In the Sino-Indian case, it is clear that political commitments and declarations of good intentions at the highest level have been instrumental in

\footnotetext{
${ }^{41}$ Rakesh Sood, "Confidence-building Measures: Regional Application of Agreed Global Principles," in Disarmament in the Last Half Century and Its Future Prospects, Disarmament Topical Papers 21 (New York: United Nations Centre for Disarmament Affairs, 1995), p. 137.

${ }^{42}$ See Khurshid Khoja, "Confidence-Building between India and Pakistan: Lessons, Opportunities and Imperatives," in Krepon et al., A Handbook of Confidence-Building Measures for Regional Security, p. 135.

${ }^{43}$ Personal communication with a senior Indian diplomat, March 1999.

${ }^{44}$ Sood, "Confidence-building Measures: Regional Application of Agreed Global Principles," p. 137.
} 
concluding the two CBM agreements. ${ }^{45}$ When bilateral relations sour, as in the aftermath of the Indian nuclear tests, the CBM process itself was affected negatively, as were the prospect and progress of implementing existing CBM provisions. A second element is that both sides prefer a gradual, step-by-step approach to developing CBMs rather than designing comprehensive ones that may turn out to be impractical. This may explain why the two CBM agreements contain only a few verifiable provisions. Finally, the concepts of "asymmetric obligations" and "relative transparency" indicate that neither India nor China is willing to embrace more constraining and transparency measures.

Actual implementation of the provisions has yet to be worked out and may highlight differences that were not anticipated at the operational level. For instance, while the 1996 agreement clearly defines the troop levels allowed to participate in military exercises (which are relatively more difficult to monitor from a technical standpoint), it does not provide the precise numbers for equipment allowed (which is technically easier to monitor) in exercises or along the border. Thus, the path of verifying the Sino-Indian CBM provisions is likely to be a complex one.

The process of implementation and verification of the CBMs is likely to be politically driven, rather than technology or treaty driven. ${ }^{46}$ The provisions in the treaty that call for monitoring and verification are unlikely to be fleshed out and implemented unless the political will moves it forward. In fact, even the presence of clear verification provisions, technological means, and monitoring regimes are unlikely to be implemented unless there is the political will to do so. Hence, the verification and monitoring models suggested in the following section will work only if the political climate is conducive for their implementation.

However, these limitations can also provide opportunities for cooperative monitoring. The fact that the verifiable provisions contained in the two CBM agreements are few and far from stringent could make it relatively easier for Beijing and New Delhi to accept the ideas of jointly collecting, analyzing, and sharing data related to implementation activities. Given the limited scope of these provisions, neither side would feel its security was compromised since verification at this stage is unlikely to be intrusive. At the same time, successful designs and implementation of workable models of cooperative monitoring can build up trust, raise the comfort level of using technologies in implementing arms control provisions, and embolden the two sides to adopt additional CBMs that are verifiable, more stringent, and in the long run conducive to consolidating better bilateral relations between India and China.

\footnotetext{
${ }^{45}$ For a discussion of how and to what extent declaratory statements of good intentions by national leaders can contribute to confidence building, see Michael Krepon, Jenny S. Drezin, and Michael Newbill, eds., Declaratory Diplomacy: Rhetorical Initiatives and Confidence Building, Report No. 27 (Washington, DC: The Stimson Center, April 1999).

${ }^{46}$ Personal communication with a former senior Indian diplomat, March 1999.
} 


\section{Three Models of Cooperative Monitoring}

Cooperative monitoring proceeds from identification of verifiable provisions of arms control and CBM agreements in question, to selection of available and appropriate technologybased tools, to specific plans that are politically acceptable to the parties and technically sound and practicable. To make the study as practical as possible, this section focuses only on those provisions of the 1993 and 1996 agreements that lend themselves to cooperative monitoring. This will be done in three steps: First, an examination of the two CBM agreements to identify those provisions that require cooperative monitoring; second, an identification of those areas along the border areas and the LAC where such cooperative monitoring is practical and likely to be effective; third, the development of cooperative monitoring models that incorporate the provisions, the areas, and the appropriate technology.

\subsection{Salient Provisions of the 1993 and 1996 Sino-Indian Agreements}

The 1993 and 1996 agreements provide a number of verifiable provisions. These include regular flag meetings, maintenance and expansion of telecommunication links, exchange of information on natural disasters and diseases, notification and limitation of military exercises, reduction of certain types of equipment (although no specific figures are given), and prevention of aerial intrusion of military aircraft within $10 \mathrm{~km}$ of the LAC. Verification of these provisions can be facilitated through bilateral cooperative monitoring measures or unilateral selfcompliance. Even where specific numbers have not been decided, cooperative monitoring would still be helpful to observe the kind of equipment that both sides have fielded and to ensure that neither side has introduced weapons that are not allowed under the agreements. With regard to military exercises, specific technical means could be used to observe that the number of troops participating is within the provisions of the treaty. However, before examining the various provisions, it would be useful to study the different areas along the Sino-Indian border to see which sectors are best suited for cooperative monitoring.

\subsection{Areas of Monitoring: Strategic Passes and Locations with Histories of Conflict}

Given the length of the entire LAC (about 2,000 km), a full-scope implementation of all the verifiable provisions of the two agreements is neither practical nor affordable. Moreover, the geographical characteristics (mountainous, rugged terrain, freezing climate, and high altitude) of the border area have restricted the likely areas of confrontation between India and China to a few predictable spots. Given this terrain, any military buildup is likely to be a slow and very visible process. Therefore, this study focuses on the potential of monitoring major roads, passes, and possible assault routes along the disputed border for three reasons. First, these areas (such as passes) have an obvious strategic value. For instance, the Spanggur Gap area near Chushul in the western sector of the Sino-Indian LAC was a key strategic site during the 1962 war and remains so today. Second, some of these, such as Bum La in the eastern sector, were the sites of past military confrontations (either during the 1962 war or the $1986-87$ conflict) and could be poten- 
tial flash points in the future. ${ }^{47}$ Third, some of these sites have been specifically identified by India and China as locations to conduct flag meetings and are, therefore, acceptable to both sides as areas where some cooperation is allowed. Based on these factors, this study focuses on one specific area: the Spanggur Gap in the western sector (see Figure 2). The inset in Figure 2 shows the area of the east edge of the Gap to the west edge of Spanggur Lake.

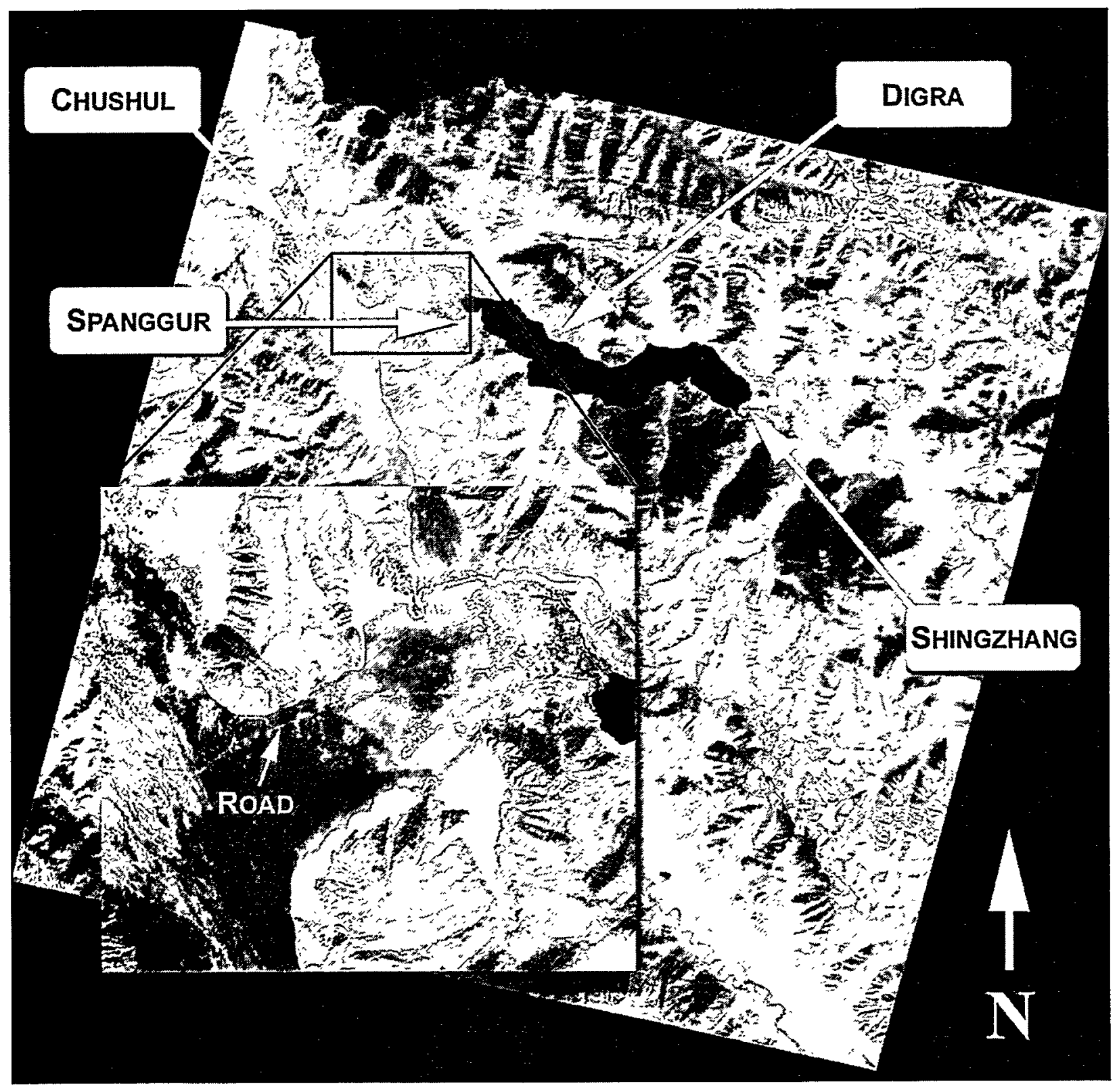

Figure 2. SPOT Image of Spanggur Lake Region, with inset of Spanggur Gap.

\footnotetext{
${ }^{47}$ See Maxwell, India's China War, and Hoffmann, India and the China Crisis, for more details.
} 
Apart from the political factors mentioned above, this area is also useful from a geographical and technological point of view. It is conducive for cooperative monitoring because major military movement is possible only through narrow passes or by air. As a result, ground sensors can assure prompt electronic notification in case a few vehicles and some personnel move through the passes, while satellite imaging and aerial surveillance can detect large military activity. However, the environment may also place severe constraints on monitoring. For instance, clouds may prevent clear satellite and aerial imaging. Heavy snow may muffle sound from vehicles while landslides and/or avalanches may bury or destroy a set of sensors. The areas sustain long periods of extremely low temperatures and this may freeze components, reduce battery life, and compromise the effective functioning of sensors. Moreover, in windy conditions, which are not uncommon, communication antennas may be blown over, losing links between monitoring sites and centers for data collecting and analyzing.

The harsh conditions would require selection and testing of specialized or specific sensor systems. This could be done through cooperative efforts by border units where engineers from both sides could perform the tests in similar environments away from the LAC (if conducting tests close to the LAC is considered too sensitive).

Once the geographical locations and the technologies have been selected, monitoring can be conducted in several manners, as follows:

- Joint operations by sharing of equipment and collecting, analyzing, and disseminating data at a joint monitoring center.

- Sharing of equipment but collecting, analyzing, and disseminating the data separately or unilaterally.

- Collecting data unilaterally but comparing it jointly.

Based on the three variables (provisions, locations, and monitoring methods) identified earlier, Table 2 illustrates the degree of acceptance and likelihood of success of a particular cooperative monitoring tool in a particular area and for a particular treaty provision. The appropriate technology has also been identified (for details of the sensors and the related technology, see Appendix G).

On the basis of the high possibility of acceptance, at least three models of cooperative monitoring can be envisioned. These are described in detail below. 
Table 2. Cooperative Monitoring Matrix

\begin{tabular}{|l|l|l|l|}
\hline \multicolumn{1}{|c|}{$\begin{array}{c}\text { Treaty and JWG } \\
\text { Provisions }\end{array}$} & \multicolumn{1}{|c|}{$\begin{array}{c}\text { Area of } \\
\text { Implementation }\end{array}$} & \multicolumn{1}{|c|}{$\begin{array}{c}\text { Methods of } \\
\text { Monitoring }\end{array}$} & \multicolumn{1}{c|}{$\begin{array}{c}\text { Possibility of } \\
\text { Acceptance }\end{array}$} \\
\hline Flag meetings & $\begin{array}{l}\text { Spanggur Gap and } \\
\text { Bum La }\end{array}$ & Ground sensors & High \\
\hline $\begin{array}{l}\text { Weather/Natural } \\
\text { Disasters }\end{array}$ & $\begin{array}{l}\text { Major passes and } \\
\text { pilgrimage routes }\end{array}$ & $\begin{array}{l}\text { Weather data collecting } \\
\text { equipment }\end{array}$ & High \\
\hline Diseases & $\begin{array}{l}\text { Major passes and } \\
\text { pilgrimage routes }\end{array}$ & $\begin{array}{l}\text { On-site disease } \\
\text { monitoring }\end{array}$ & Medium to Low \\
\hline $\begin{array}{l}\text { Disengagement from } \\
\text { four posts }\end{array}$ & $\begin{array}{l}\text { Sumdorong Chu } \\
\text { Valley }\end{array}$ & $\begin{array}{l}\text { Baseline on-site } \\
\text { inspections (OSIs); } \\
\text { ground sensors, and } \\
\text { aerial monitoring }\end{array}$ & $\begin{array}{l}\text { Medium to High but } \\
\text { may be technically }\end{array}$ \\
\hline $\begin{array}{l}\text { Military exercises } \\
\text { limitation and prior } \\
\text { notification }\end{array}$ & $\begin{array}{l}\text { Strategic passes } \\
\text { fought over in 1962 } \\
\text { and 1986-87; } \\
\text { Sikkim }\end{array}$ & $\begin{array}{l}\text { Satellite imaging, } \\
\text { Open Skies, } \\
\text { remote sensing, } \\
\text { ground sensors, } \\
\text { hot lines, and } \\
\text { garrison monitoring }\end{array}$ & $\begin{array}{l}\text { Medium to High } \\
\text { potential for greater } \\
\text { cooperative monitoring }\end{array}$ \\
\hline $\begin{array}{l}\text { Limitation on } \\
\text { armament and } \\
\text { equipment }\end{array}$ & $\begin{array}{l}\text { Rajtine OSIs, } \\
\text { garrison monitoring, } \\
\text { ground sensors, and } \\
\text { aerial monitoring }\end{array}$ & $\begin{array}{l}\text { Low potential for } \\
\text { cooperative monitoring } \\
\text { at the moment }\end{array}$ \\
\hline
\end{tabular}

\subsection{The Short-Term Model}

This model would build on the existing practice of flag meetings. Currently the flag meetings take place twice a year in June and October and require little or no technology or cooperative monitoring. However, it is feasible that under the provision of the agreements, a hot line may be installed between the two area commanders to increase the level of communication and perhaps even increase the frequency of the meetings. The installation of the hot line itself would be a CBM and its regular maintenance, particularly in the harsh climate of the Spanggur Gap and Bum La areas, would involve some cooperation. In addition, it is also possible that the flag meetings may be expanded to include group interactions; for instance, at the company level, these activities could include friendly soccer games among the troops posted in that particular area. ${ }^{48}$ This increased level of interaction, particularly if it were formalized, would also require additional communication and cooperation on both sides. Thus the first significant technology input would have to be the means to ensure regular and reliable communications.

\footnotetext{
${ }^{48}$ Such activities are already taking place at an impromptu and ad hoc level. For instance, in March 1999 the Indian Army Chief, General V.P. Malik, spontaneously crossed the LAC at Nathu La and greeted the Chinese soldiers with sweets.
} 
Another area of cooperation and cooperative monitoring that is likely to find a high level of acceptance on both sides is the collection and dissemination of weather data as well as assistance during natural disasters. Clearly, both sides already collect weather and other related data, but currently this is done unilaterally. It is conceivable that the two sides could agree to either share weather information or gather it jointly. Thus, as part of the improved communications mentioned earlier, it is possible that initially the weather data collected unilaterally could be exchanged electronically as a CBM. Subsequently both sides could also establish joint weather data collection centers. Here again, the Spanggur Gap area could be used as a test bed to collect and share weather data.

In addition, the communication link for weather could form the basis for cross-border information exchanges on disaster relief, smuggling, disease outbreaks, and other items of local interest. Although most of these are inapplicable to the Spanggur Gap area and are more useful along trade routes and routes used by pilgrims, the Spanggur Gap area could become a model site for experimental disease and natural disaster reporting, which could be replicated to other areas if the experiment is successful. This may be particularly pertinent given that a landslide last year killed more than 200 Kailash Mansarovar pilgrims. India has already suggested opening an alternate route for the annual pilgrimage to Mansarovar in Tibet. ${ }^{49}$ Here the two sides could explore some measures of cooperative weather data gathering and monitoring.

\subsection{The Medium-Term Model}

The installation of ground sensors on both sides of the LAC is important to detect unannounced troop movements, clarify misunderstandings, and increase the level of confidence in the peaceful intentions of the other side. Here the Spanggur Gap area is an ideal setting. Nestled between the Spanggur Lake in the south and the 14,229-foot-high Chushul Mountain in the north, the 2-km-wide gap is a natural pass. With little or no civilian traffic, it is a nearperfect setting to establish a model cooperative monitoring regime using ground sensors. These sensors could be placed on passes, roads, and/or garrison gates and could be combined with cameras for video assessments.

Using simulation software such as Simtool, ${ }^{50}$ it would be possible to design a laboratory experimental simulation of ground sensors at the Spanggur Gap to explore virtually how they would operate. The simulation allows for different sensors to be placed on a map of the Spanggur Gap area and to see where the optimum location is to place these sensors and under what conditions (the passage of men or vehicles) they might be triggered. The model is also useful in determining what the optimum sensors would be for a particular location, both in terms of cost and technology. See Figure 3 for illustration.

\footnotetext{
49 "Sino-Indian talks positive: MEA," The Hindustan Times, March 1, 1999, http://www.hindustantimes. com/nonfram/010399/DetFOR05.htm.

${ }^{50}$ A program developed by Sandia National Laboratories for the Cooperative Monitoring Center, Albuquerque, New Mexico.
} 


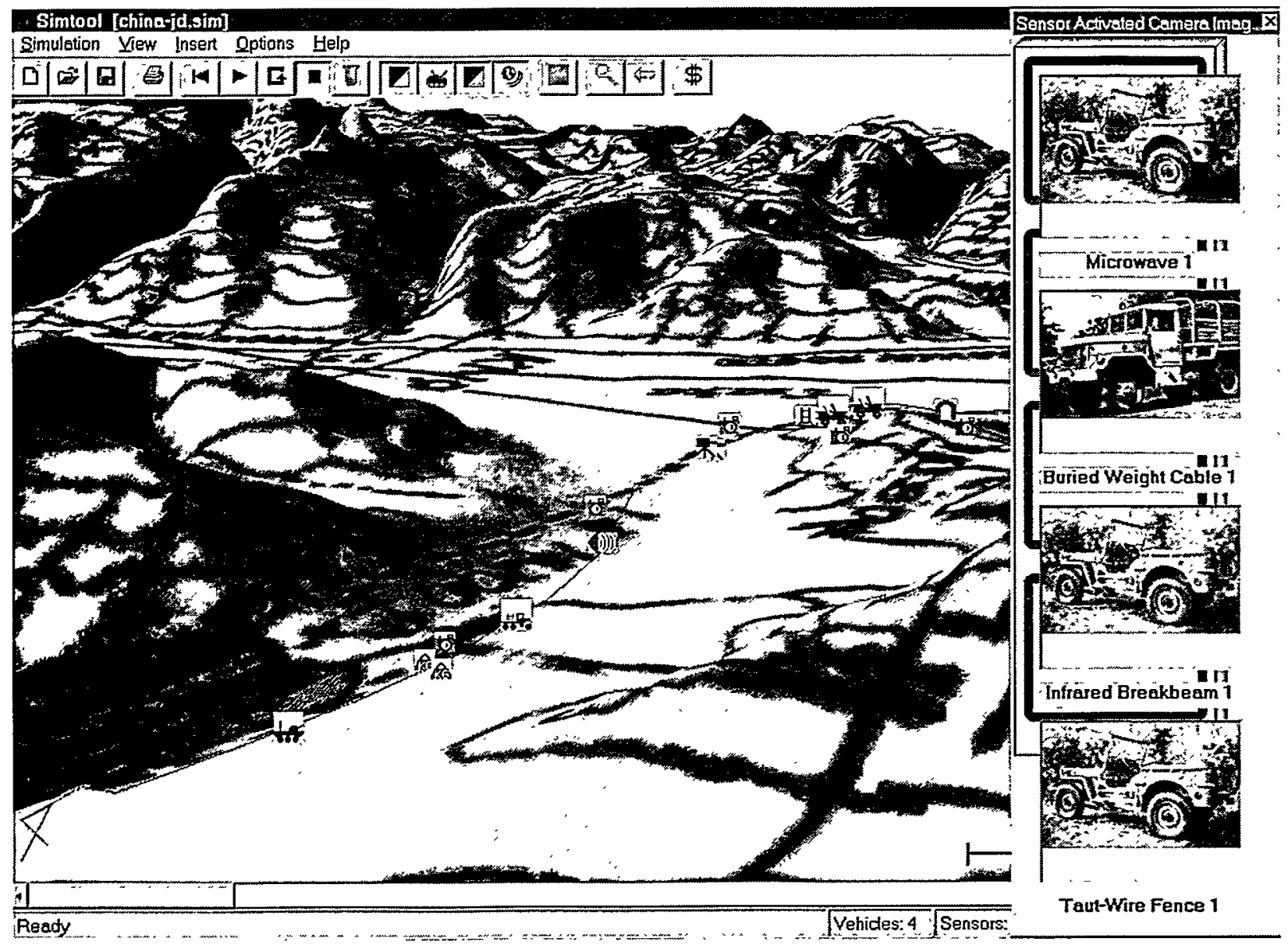

\section{Figure 3. Simulated Demonstration of Sensor Deployment and Activation in the Spanggur Gap.}

A deployed cooperative monitoring system can serve several purposes. At the simplest level, it can merely announce the arrival of the other side's delegation for flag meetings (convoy consisting mostly of light vehicles such as jeeps). More substantially, it can monitor inadvertent intrusions of patrol groups or detect intentional troop movements at a larger scale, for instance, ones that contain armed personnel carriers, infantry combat vehicles, and other heavy equipment that are limited by the two agreements. The sensors can be placed along the Spanggur Gap, which is about two kilometers wide. A combination of seismic, magnetic, and linear (weigh cables, infrared, microwave) sensors, placed at strategic locations along the way, would complement each other in identifying and detecting movements of equipment and personnel. As vehicles move faster and therefore require longer warning time, weight cables, seismic, and magnetic sensors should be placed at the far ends of passes and linked to cameras. A center for receiving and analyzing data could be set up at a location mutually agreed to and staffed with personnel from both sides. Communication links would also be established between the center, the frontline command posts of both sides, and the forward patrol posts to facilitate clarification of ambiguous situations. The standard would be that the less tension between the two countries, the fewer sensors would be required. Analysis could be done jointly; otherwise, we expect more sensors, with collecting and analyzing done unilaterally. 
One of the more significant breakthroughs in Sino-Indian relations was the disengagement of Indian and Chinese troops from four border posts in the Sumdorong Chu area in 1995, where they had been in an eyeball-to-eyeball confrontation ever since a major showdown in $1987 . .^{51}$ Although the disengagement was regarded as a sign of normalization by both sides, this is an opportunity that calls for cooperative monitoring arrangements to ensure that the four posts do not become the source of a future dispute.

Such a situation calls for a monitoring regime that could increase confidence on both sides by providing reassuring information that neither was trying to reoccupy the posts. Although the disengagement was negotiated by the JWG, so far there is no consensus to monitor the posts to ensure that they are not reoccupied. However, were such a provision to be reached, the disengagement could be monitored by a combination of ground sensors, aerial surveillance, and on-site inspections. Here the experience gained in the experimentation with ground sensors both through Simtool and on the ground at Spanggur Gap would be useful.

Given the geographical characteristics of the LAC, particularly in the Sumdorong Chu area, a kind of "open skies" monitoring regime would be ideal. The agreements also allow for this type of aerial survey. For instance, Article V of the 1996 Agreement specifies that "survey aircraft shall be permitted to fly up to the line of actual control." An "open skies" monitoring regime could allow regular aerial surveillance, flexible routing, and short-notice missions. This would be less intrusive than on-site inspections and offers high-resolution imaging at low altitude and at a manageable cost. The only issue then is how comfortable both India and China would be in allowing such a regime, considering that neither side has ever carried out such a task jointly. This presents an excellent opportunity for cooperative monitoring at a reduced cost. The European experience can serve as a useful precedent in this regard.

Another method of aerial surveillance is through satellite imaging. The increasing importance and availability of satellite images and how they bear on national, regional, and international security has been noted by both analysts and policy makers. ${ }^{52}$ Recent studies, including one on detecting massed troops along the Saudi-Iraq border during the 1991 Gulf War and another on the South China Seas using satellites, are helpful in this context. ${ }^{53}$ Overall, satellite images can be useful for cooperative monitoring purposes as they can be quite adequate in detecting masses of vehicles, garrison embankments, staging areas, tank-training ranges, and supply roads from a high altitude and therefore with wide coverage. Equipped with radar, they can also overcome problems arising from cloud cover or other bad weather and still be able to provide high-resolution imagery. Satellites, once placed in orbit, do not require permission to enter the air space of countries in question.

\footnotetext{
${ }^{51}$ At the eighth JWG meeting in August 1995, the two sides agreed to pull back troops from four posts within 50-100 yards from each other in the Sumdorong Chu Valley (Wangdung area). See Singh, "Sino-Indian CBMs"; Hua Han, "Sino-Indian relations and nuclear arms control," in Eric Arnett, ed., Nuclear Weapons and Arms Control in South Asia after the Test Ban (Oxford: SIPRI and Oxford University Press, 1998), p. 40.

52 Vipin Gupta, “New Satellite Images for Sale," International Security 20:2 (Summer 1995), pp. 94-125.

${ }^{53}$ Vipin Gupta and George Harris, Detecting Massed Troops with the French SPOT Satellites: A Feasibility Study for Cooperative Monitoring, CMC Occasional Paper (January 1999).
} 
From the comparison above it would appear that in the case of monitoring the four posts in the Sumdorong Chu area, an aircraft-based monitoring system would be preferable to satellite imagery. While satellite imagery is useful to monitor troops concentrated at the brigade level in places with distinct man-made structures, it may be less effective when the number of troops involved is much smaller and the terrain features (trees, bushes, and narrow valleys) can cover up human activity. Thus, aerial monitoring, such as the "Open Skies" provision in the CFE context and the Hungary-Romania bilateral regime (using aircraft), can also provide some useful precedent for the India-China case.

Both India and China already are carrying out unilateral on-site inspections of the four posts in the Sumdorong Chu area to make sure that the other side has not reoccupied them. However, this could be extended into bilateral, cooperative OSIs using baseline OSIs. For instance, the two sides could decide on a mutually agreed level of personnel and equipment and introduce sensors at garrison gates to ensure that a baseline is both agreed to and maintained. In addition, they could also opt for joint patrols (which was done in the past), or they could decide to conduct regular flag meetings at the site of the disputed posts to ensure that neither side has violated its declaration. These regular meetings could be supplemented by challenge OSIs that would initially have to be confined to the four posts but could possibly be extended to other posts on both sides at a later date.

\subsection{The Long-Term Model}

In the long term, the agreements call for the reduction of troops and the limitation of military equipment allowed along the border areas. Cooperative monitoring is the best way to ensure adherence to these provisions. However, before this can be accomplished, there will first have to be a negotiation of the numbers of arms and armament allowed. At the moment, there are no specific numbers. ${ }^{54}$ However, given that military exercises are not allowed beyond the brigade level, it can be assumed that the equipment would also relate to that which is normally attached to brigade-level units. Hence, to begin it would be adequate to determine the equipment composition of both the Chinese and Indian forces at the brigade level and above and set the base line. This would be in conformity with the troop levels permitted under the agreements.

Although the implementation of this model is likely only if there is sufficient political will on both sides, it would be the most intrusive of the cooperative monitoring models suggested so far. It would not be confined only to the border areas, but might have to be extended to the staging areas deep in India and China, where troops and equipment larger than a brigade level can be assembled. It might even call for monitoring of garrisons away from the LAC and deep within Chinese and Indian territory. Once forces had been set and verified at the permitted level, garrison monitoring would provide the day-to-day confirmation that the forces were within the garrison. The sensors would also confirm declarations of force exits or entries as needed for exercises, etc.

\footnotetext{
${ }^{54}$ Various Chinese accounts have assigned 240,000 Indian troops vs. 40,000 Chinese along the Sino-Indian border areas and LAC. Han, "Sino-Indian relations," p. 42. However, the Indian sources suggest that China may maintain between 180,000 and 300,000 troops in Tibet. See, for example, Singh, "Sino-Indian CBMs."
} 
In addition to ground sensors, aerial surveillance, and the limited on-site inspections already described in the previous sections, a specific model would have to be jointly developed to monitor garrisons. Proper selection, by both sides in cooperation, would guarantee detection of forces that exit the garrison but not detect permitted movement within the garrison perimeter. The objective is to ensure that the military security of each side is preserved. The use of electronic sensors, thus organized, assures that only the agreed data are transmitted. Remote monitoring of garrison gates by the installation of checkpoint systems would provide notification of entry or exit by military vehicles, report attempted bypass of the system, and screen for anomaly in vehicle length and weight, which could be picked up by break-beam and weight sensors. Replacement of human inspectors is not a cost measure, but rather would make the system less intrusive. Reducing the chance of false "events" from civilian activities, animal life, and weather would also be an important consideration.

\subsection{Some Constraints and a Realistic Assessment}

While China and India have made great strides in confidence building over the past two decades and the two CBM agreements do provide some verifiable provisions, obstacles remain in implementation. Political, economic, and technological constraints take time and great efforts to overcome. The three models suggest that cooperative monitoring may be possible, and indeed should be undertaken. The options range from the relatively easy, information-exchange CBMs, and move gradually toward more stringent verification as the two sides build trust and gain confidence in understanding technology-based tools. In this regard, effective implementation of existing provisions require the two sides to face and overcome both political and technological challenges. The first has never been easy and has become more complicated in the aftermath of Indian nuclear testing, in addition to residual conflicts between the two countries over a range of issues. Even if the political will existed, the complexity of verification and monitoring through the application of various technical means, coupled with the geographical realities, would make cooperative monitoring at once daunting and rewarding. The U.S.-Soviet, European, and Sinai modalities have demonstrative rather than transplantive significance; they have taken a long time to gain experience. In the Sino-Indian context, there is much less experience about, let alone inclination toward, verification in bilateral settings.

Second, there are economic constraints that must also be taken into consideration. Technology both saves and consumes resources. Along the 2,000-km Sino-Indian LAC, there are a number of strategic passes where military operations could take place and indeed did take place in the past. It would be very costly to monitor all of them; both countries remain essentially developing countries with large populations and limited economic resources. Of necessity, cooperative monitoring should be limited in scale, and at the beginning should be for demonstrative purposes. High-technology, high-budget solutions would not be appropriate here; the distances are too vast and the support technology is not highly advanced in these remote areas. An ambitious design would be out of the question at this point.

Finally, the Sino-Indian case cautions against transplanting cooperative monitoring models from elsewhere because of the technological challenges the two countries face. Neither country has had experience in designing and developing monitoring models that incorporate the use of various technology-based tools. This would require personnel training in equipment 
operation and maintenance. The training itself would be a valuable CBM. While the uniqueness of potential application in the Sino-Indian case makes this a good area of technical cooperation, the cooperation itself takes time to develop. Agreeing on, designing, field-testing, and procuring a complete system could take several years.

\section{Conclusions}

Several conclusions can be drawn from this study. The first is that unlike in other regions where studies have been made of the potential and applicability for cooperative monitoring, such as the Sinai Peninsula and the Korean Demilitarized Zones (DMZs), the Sino-Indian LAC represents neither an immediate post-conflict situation where disengagement of military forces would be of foremost importance, nor is it in a situation of perennial intense military confrontation that requires constant surveillance and monitoring. Rather, it is a long-term issue of a relatively stable nature. Here no imminent conflict is anticipated, let alone massive military clashes over the border areas. There are two CBM agreements that India and China have signed that contain, however limited, certain provisions for military reduction, disengagement, and confidence building. Implementation, if for no other reason than to testify to the sincerity of commitments to better relations on both sides, provides both the rationale and testing ground for exploring the possibility of cooperative monitoring. Given the limited nature of the verifiable provisions contained in both documents, some degree of intrusiveness and/or "transparency" should not undermine the security of either country.

A second conclusion is that cooperative monitoring both as a concept and practice presents challenges and opportunities for China and India, given their emphasis on sovereignty and military confidentiality, and their general views on transparency and verification. This study therefore has explored the potential role that cooperative monitoring can play in facilitating implementation of verifiable provisions. While well-thought-out monitoring models are indispensable in ensuring that agreements be carried out properly, the more fruitful outcome of this study is to dispel misperceptions about verification in Beijing and New Delhi. We hope to present a strong case that sharing information does not necessarily compromise security; on the contrary, cooperative monitoring can encourage the two countries to build trust and gain confidence, leading to more detailed and verifiable arms control provisions.

Third, cooperative monitoring in the Sino-Indian case could be designed in ways that would start in small scale, and move from the relatively easy to the more complex. The three models we presented in the paper are based on this premise. The minimalist model for the short term could be applied relatively easily as it deals with activities (such as flag meetings, natural disaster reporting, and disease prevention) that both sides are either already undertaking or would benefit from greater cooperation. The technology used is simple and within the competence of both countries and therefore would provide an ideal environment for them to learn the basic principles of cooperative monitoring. The medium-term model deals with the more practical CBM provisions that impose constraints on both sides, as well as require a certain degree of intrusiveness and transparency. The successful design and application of this model is crucial, in that positive experience not only can facilitate effective implementation of the verifiable provisions, but also could influence how Beijing and New Delhi think about CBMs, military 
transparency, and verification. This may be highly beneficial as India contemplates future confidence building with Pakistan.

Finally, we recognize the political, economic, and technological constraints of designing and implementing cooperative monitoring models in the Sino-Indian context. This is true both in the case of our maximalist or long-term model and in the two other models as well. Political will remains an essential element in determining if cooperative monitoring could happen and to what extent it could be implemented. In addition, there are significant economic and technological challenges, given the two countries' economic resources that could be committed to this area and the expertise that would need to be acquired and developed. This indicates that cooperative monitoring models take time to develop, should be realistic and practical, and experimental at the beginning. Our purpose is to use the models presented in the paper to demonstrate both the potential positive role that cooperative monitoring can play and identify potential limitations. This may be particularly useful in the aftermath of the Indian nuclear tests, in that efforts are needed from both sides to re-engage and resume the stalled process of confidence building and normalization. 


\title{
APPENDIX A: 1993 CBM Agreement on Peace and Tranquility
}

\author{
AGREEMENT ON THE MAINTENANCE OF PEACE AND TRANQUILITY IN THE BORDER AREAS ALONG \\ THE LINE OF ACTUAL CONTROL (BEIJING, SEPTEMBER 7, 1993)
}

The Government of the Republic of India and the Government of the People's Republic of China (hereinafter referred to as the two sides), have entered into the present agreement in accordance with the five principles of mutual respect for sovereignty and territorial integrity, mutual non-aggression, non-interference in each other's internal affairs, equality and mutual benefit and peaceful coexistence and with a view to maintaining peace and tranquillity in areas along the Line of Actual Control (LAC) in the India-China border areas.

\section{Article 1}

The two sides are of the view that the India-China boundary question shall be resolved through peaceful and friendly consultations. Neither side shall use or threaten to use force against the other by any means. Pending an ultimate solution to the boundary question between the two countries, the two sides shall strictly respect and observe the LAC between the two sides. No activities of either side shall overstep the LAC. In case personnel of one side cross the LAC, upon being cautioned by the side, they shall immediately pull back to their own side of the LAC. When necessary, the two sides shall jointly check and determine the segments of the LAC where they have different views as to its alignments.

\section{Article 2}

Each side will keep its military forces in the areas along the LAC to a minimum level compatible with the friendly and good-neighborly relations between the two countries. The two sides agree to reduce their military forces along the LAC in conformity with the requirements of the principle of mutual and equal security to ceilings to be mutually agreed upon. The extent, depth, timing and nature of reduction of military forces along the LAC shall be determined through mutual consultations between the two countries. The reduction of military forces shall be carried out by stages in mutually agreed geographical locations sectorwise within the areas along the LAC.

\section{Article 3}

Both sides shall work out through consultations effective confidence building measures in the areas along the LAC. Neither side will undertake specified levels of military exercises in mutually identified zones. Each side shall give the other prior notification of military exercises of specified levels near the LAC permitted under this agreement.

\section{Article 4}

In case of contingencies or other problems arising in the areas along the LAC, the two sides shall deal with them through meetings and friendly consultations between border personnel of the two countries. The form of such meetings and channels of communications between the border personnel shall be mutually agreed upon by the two sides.

\section{Article 5}

The two sides agree to take adequate measures to ensure that air intrusions across the LAC do not take place and shall undertake mutual consultations should intrusions occur. Both sides shall also consult on possible restrictions on air exercises in areas to be mutually agreed near the LAC.

\section{Article 6}

The two sides are agreed that references to the LAC in this agreement do not prejudice their respective positions on the boundary question. 


\section{Article 7}

The two sides shall agree through consultations on the form, method, scale and content of effective verification measures and supervision required for the reduction of military forces and the maintenance of peace and tranquillity in the areas along the LAC under this agreement.

\section{Article 8}

Each side of the India-China Joint Working Group on the boundary question shall appoint diplomatic and military experts to formulate, through mutual consultations, implementation measures for the present agreement. The experts shall advise the Joint Working Group on the resolution of differences between the two sides on the alignment of the LAC and address issues relating to redeployment with a view to reduction of military forces in the areas along the LAC. The experts shall also assist the Joint Working Group in supervision of the implementation of the agreement, and settlement of differences.

\section{Article 9}

The present agreement shall come into effect as of the date of signature and is subject to amendment and addition by agreement of the two sides. 


\title{
APPENDIX B: 1996 Agreement on Military CBMs
}

\author{
AGREEMENT BETWEEN THE GOVERNMENT OF THE REPUBLIC OF INDIA AND THE GOVERNMENT OF \\ THE PEOPLE'S REPUBLIC OF CHINA ON CONFIDENCE-BUILDING MEASURES IN THE MILITARY FIELD \\ ALONG THE LINE OF ACTUAL CONTROL IN THE INDIA-CHINA BORDER AREAS (NEW DELHI, \\ DECEMBER 1996)
}

The Government of the Republic of India and the Government of the People's Republic of China (hereinafter referred to as the two sides).

Believing that it serves the fundamental interests of the peoples of India and China to foster a long-term good-neighborly relationship in accordance with the five principles of mutual respect for sovereignty and territorial integrity, mutual nonaggression, non-interference in each other's internal affairs, equality and mutual benefit and peaceful co-existence.

Convinced that the maintenance of peace and tranquillity along the line of actual control in the India-China border areas accords with the fundamental interests of the two peoples and will also contribute to the ultimate resolution of the boundary question.

Reaffirming that neither side shall use or threaten to use force against the other by any means or seek unilateral military superiority.

Pursuant to the Agreement between the Government of the Republic of India and the Government of the People's Republic of China on the Maintenance of Peace and Tranquillity along the Line of Actual Control in the India-China Border Areas, signed on September 7, 1993.

Recognizing the need for effective confidence building measures in the military field along the line of actual control in the border areas between the two sides.

Noting the utility of confidence building measures already in place along the line of actual control in the India-China border areas.

Committed to enhancing mutual confidence and transparency in the military field.

Have agreed as follows:

\section{Article I}

Neither side shall use its military capability against the other side. No armed forces deployed by either side in the border areas along the line of actual control as part of their respective military strength shall be used to attack the other side, or engage in military activities that threaten the other side or undermine peace, tranquillity and stability in the India-China border areas.

\section{Article II}

The two sides reiterate their determination to seek a fair, reasonable and mutually acceptable settlement of the boundary question. Pending an ultimate solution to the boundary question, the two sides reaffirm their commitment to strictly respect and observe the line of actual control in the India-China border areas. No activities of either side shall overstep the line of actual control.

\section{Article III}

The two sides agree to take the following measures to reduce or limit their respective military forces within mutually agreed geographical zones along the line of actual control in the India-China border areas:

(1) The two sides reaffirm that they shall reduce or limit their respective military forces within mutually agreed geographical zones along the line of actual control in the India-China border areas to minimum levels compatible with 
the friendly and good neighborly relations between the two countries and consistent with the principle of mutual and equal security.

(2) The two sides shall reduce or limit the number of field army, border defense forces, para-military forces and any other mutually agreed category of armed force deployed in mutually agreed geographical zones along the line of actual control to ceilings to be mutually agreed upon. The major categories of armaments to be reduced or limited are as follows: combat tanks, infantry combat vehicles, guns (including howitzers) with $75 \mathrm{~mm}$ or bigger caliber, mortars with $120 \mathrm{~mm}$ or bigger caliber, surface-to-surface missiles, surface-to-air missiles and any other weapon system mutually agreed upon.

(3) The two sides shall exchange data on the military forces and armaments to be reduced or limited and decide on ceilings on military forces and armaments to be kept by each side within mutually agreed geographical zones along the line of actual control in the India-China border areas. The ceilings shall be determined in conformity with the requirement of the principle of mutual and equal security, with due consideration being given to parameters such as the nature of terrain, road communication and other infrastructure and time taken to induct/deinduct troops and armaments.

\section{Article IV}

In order to maintain peace and tranquillity along the line of actual control in the India-China border areas and to prevent any tension in the border areas due to misreading by either side of the other side's intentions:

(1) Both sides shall avoid holding large-scale military exercises involving more than one Division (approximately 15,000 troops) in close proximity of the line of actual control in the India-China border areas. However, if such exercises are to be conducted, the strategic direction of the main force involved shall not be towards the other side.

(2) If either side conducts a major military exercise involving more than one Brigade Group (approximately 5,000 troops) in close proximity of the line of actual control in the India-China border areas, it shall give the other side prior notification with regard to type, level, planned duration and area of exercise as well as the number of type of units or formations participating in the exercise.

(3) The date of completion of the exercise and deinduction of troops from the area of exercise shall be intimated to the other side within five days of completion or deinduction.

(4) Each side shall be entitled to obtain timely clarification from the side undertaking the exercise in respect of data specified in Paragraph 2 of the present Article.

\section{Article V}

With a view to preventing air intrusions across the line of actual control in the India-China border areas and facilitating overflights and landings by military aircraft:

(1) Both sides shall take adequate measures to ensure that air intrusions across the line of actual control do not take place. However, if an intrusion does take place, it should cease as soon as detected and the incident shall be promptly investigated by the side operating the aircraft. The results of the investigation shall be immediately communicated, through diplomatic channels or at border personnel meetings, to the other side.

(2) Subject to Paragraphs 3 and 5 of this Article, combat aircraft (to include fighter, bomber, reconnaissance, military trainer, armed helicopter and other armed aircraft) shall not fly within ten kilometers of the line of actual control.

(3) If either side is required to undertake flights of combat aircraft within ten kilometers from the line of actual control, it shall give the following information in advance to the other side, through diplomatic channels:

(a) Type and number of combat aircraft;

(b) Height of the proposed flight (in meters);

(c) Proposed duration of flights (normally not to exceed ten days);

(d) Proposed timing of flights; and 
(4) Area of operations defined in latitude and longitude.

(5) Unarmed transport aircraft, survey aircraft and helicopters shall be permitted to fly up to the line of actual control.

No military aircraft of either side shall fly across the line of actual control, except by prior permission. Military aircraft of either side may fly across the line of actual control or overfly the other side's airspace or land on the other side only after obtaining the latter's prior permission after providing the latter with detailed information on the flight in accordance with the international practice in this regard,

Notwithstanding the above stipulation, each side has the sovereign right to specify additional conditions, including at short notice, for flights or landings of military aircraft of the other side on its side of the line of actual control or through its airspace.

(6) In order to ensure flight safety in emergency situations, the authorities designated by the two sides may contact each other by the quickest means of communications available.

\section{Article VI}

With a view to preventing dangerous military activities along the line of actual control in the India-China border areas, the two sides agree as follows:

(1) Neither side shall open fire, cause bio-degradation, use hazardous chemicals, conduct blast operations or hunt with guns or explosives within two kilometers from the line of actual control. This prohibition shall not apply to routine firing activities in small arms firing ranges.

(2) If there is a need to conduct blast operations within two kilometers of the line of actual control as part of developmental activities, the other side shall be informed through diplomatic channels or by convening a border personnel meeting, preferably five days in advance.

(3) While conducting exercises with live ammunition in areas close to the line of actual control, precaution shall be taken to ensure that a bullet or a missile does not accidentally fall on the other side across the line of actual control and causes harm to the personnel or property of the other side.

(4) If the border personnel of the two sides come in a face-to-face situation due to differences on the alignment of the line of actual control or any other reason, they shall exercise self-restraint and take all necessary steps to avoid an escalation of the situation. Both sides shall also enter into immediate consultations through diplomatic and/or other available channels to review the situation and prevent any escalation of tension.

\section{Article VII}

In order to strengthen exchanges and cooperation between their military personnel and establishments in the border areas along the line of actual control, the two sides agree:

(1) To maintain and expand the regime of scheduled and flag meetings between their border representatives at designated places along the line of actual control;

(2) To maintain and expand telecommunication links between their border meeting points at designated places along the line of actual control;

(3) To establish step-by-step medium and high-level contacts between the border authorities of the two sides.

\section{Article VIII}

(1) Should the personnel of one side cross the line of actual control and enter the other side because of unavoidable circumstances like natural disasters, the other side shall extend all possible assistance to them and inform their side, as soon as possible, regarding the forced or inadvertent entry across the line of actual control. The modalities of return of the concerned personnel to their own side shall be settled through mutual consultation. 
(2) The two sides shall provide each other, at the earliest possible, with information pertaining to natural disasters and epidemic diseases in contiguous border areas, which might affect the other side. The exchange of information shall take place either through diplomatic channels or at border personnel meetings.

\section{Article IX}

In case a doubtful situation develops in the border region, or in case one of the sides has some questions or doubts regarding the manner in which the other side is observing this Agreement, either side has the right to seek a clarification from the other side. The clarifications sought and replies to them shall be conveyed through diplomatic channels.

\section{Article X}

(1) Recognizing that the full implementation of some of the provisions of the present agreement will depend on the two sides arriving a t common understanding of the alignment of the line of actual control in the India-China border areas, the two sides agree to speed up the process of clarification and confirmation of the line of actual control. As an initial step in this process, they are clarifying the alignment of the line of actual control in those segments where they have different perceptions. They also agree to exchange maps indicating their respective perceptions of the entire alignment of the line of actual control as soon as possible.

(2) Pending the completion of the process of clarification and confirmation of the line of actual control, the two sides shall work out modalities for implementing confidence building measures envisaged under this Agreement on an interim basis, without prejudice to their respective positions on the alignment of the line of actual control as well as on the boundary question.

\section{Article XI}

Detailed implementation measures required under Article I to Article $X$ of this Agreement shall be decided through mutual consultations in the India-China Joint Working Group on the Boundary Question. The India-China Diplomatic and Military Expert Group shall assist the India-China Joint Working Group in devising implementation measures under the Agreement.

\section{Article XII}

This Agreement is subject to ratification and shall enter into force on the date of exchange of instruments of ratification. It shall remain in effect until either side decided to terminate it after giving six months' notice in writing. It shall become invalid six months after the notification.

This Agreement is subject to amendment and addition by mutual agreement in writing between the two sides.

Signed in duplicate in New Delhi on November 29, 1996 in the Hindi, Chinese and English languages, all three texts being equally authentic. In case of divergence, the English text shall prevail. 


\section{APPENDIX C: Chronology Of Sino-Indian Relations, 1947-1999}

$\underline{1947}$

August 15. India achieved independence from British rule.

$\underline{1949}$

October 1. The People's Republic of China (PRC) was established.

December 30. Indian Prime Minister Nehru announced that India recognized the new government in Beijing.

$\underline{1950}$

April 1. China and India established diplomatic relations.

$\underline{1954}$

April. China and India signed the Panchsheel Agreement and co-issued the Five Principles of Peaceful Co-existence.

$\underline{1962}$

October 21 - November 20. China and India fought a brief border war.

$\underline{1964}$

October 16. China tested its first atomic bomb.

$\underline{1974}$

May 18. India conducted its first nuclear test.

$\underline{1976}$

July. Indian Ambassador arrived in Beijing.

September. Chinese Ambassador arrived in New Delhi.

$\underline{1979}$

February. Indian Foreign Minister Atal Bihavi Vajpayee visited China.

$\underline{1980}$

June 21. Chinese Vice-Premier Deng Xiaoping proposed a "package" deal in an interview with an Indian journalist. He suggested that the boundary issue be resolved on the basis of Chinese recognition of the LAC in the eastern sector in exchange for Indian recognition of the status quo in the western sector.

$\underline{1981}$

June. Chinese Foreign Minister Huang Hua visited India. 
$\underline{1981}$

December 10-14. Sino-Indian negotiators began first round of border negotiations in Beijing. $\underline{1985}$

September. Chinese Premier Zhao Ziyang and Indian Prime Minister Rajiv Gandhi met at the United Nations.

\section{6}

December. China protested the establishment of the Arunachal Pradesh from the North East Frontier Agency.

\section{$\underline{1986-1987}$}

Chinese and Indian troops faced each other in the Sumdorong Chu Valley in the eastern sector of the Sino-Indian border/LAC. Both sides mobilized forces and the stand-off nearly escalated to open conflict. The Indian Army conducted large-scale military exercises code-named Operation Chequerboard (October 1986-March 1987).

$\underline{1987}$

November 14-17. The eighth and last round of the Sino-Indian border negotiations was held in New Delhi.

\section{$\underline{1988}$}

December 19-23. Indian Prime Minister Rajiv Gandhi made a historical visit to China. This was the first such visit in 34 years. Gandhi met with China's paramount leader Deng Xiaoping during the visit. The two sides agreed to establish a Joint Working Group (JWG) on the boundary question.

\section{$\underline{1989}$}

July. The first meeting of JWG was held in Beijing.

$\underline{1991}$

December 11-16. Chinese Premier Li Peng visited India and held talks with Indian Prime Minister P.V. Narasimha Rao.

\section{2}

February 20-21. At the fourth JWG meeting held in New Delhi, China and India agreed that military personnel of both sides would hold flag meetings twice a year (June and October) at Bum La Pass in the eastern sector and Spanggur Gap in the western sector.

May. Indian President R. Venkataraman visited China.

July. Indian Defense Minister Sharad Pawar visited China. 


\section{$\underline{1993}$}

September 6-9. Indian Prime Minister Narasimha Rao visited China. The two sides signed the Agreement on the Maintenance of Peace and Tranquility along the Line of Actual Control in the India-China Border Areas. It was decided that a Military and Diplomatic Experts Group would be set up within the JWG.

\section{$\underline{1994}$}

February. The first meeting of the Military and Diplomatic Experts Group was held in New Delhi to sort out the differences between the two sides on demarcation of the LAC and reduction of troops along the border areas.

April. The second meeting of the Military and Diplomatic Experts Group was held in Beijing with continued progress made in defining the LAC, force reductions, and other CBMs.

September. Chinese Defense Minister General Chi Haotian visited India.

\section{6}

November 28-30. Chinese President Jiang Zemin visited India. The two countries signed the Agreement on Confidence-Building Measures in the Military Field along the Line of Actual Control in the India-China Border Areas.

\section{$\underline{1998}$}

April. Chinese People's Liberation Army (PLA) Chief of the General Staff Gen. Fu Quanyou visited India.

May 11 and 13. India conducted nuclear tests. Bilateral relations deteriorated.

\section{$\underline{1999}$}

April 26-27. The 11th Sino-Indian JWG meeting was held in Beijing and both sides sought to restore the battered bilateral relationship.

June 14-16. Indian Foreign Minister Jaswant Singh visited China amidst heightened tension between India and Pakistan in Kashmir. The two sides agreed to hold security dialogues and border talks this year. 


\section{Appendix D: Sino-Indian High-Level Exchange Visits, 1979-1999}

\begin{tabular}{|c|c|}
\hline Date & Action \\
\hline February 1979 & Indian Foreign Minister Atal Bihavi Vajpayee visited China. \\
\hline May 1980 & $\begin{array}{l}\text { Chinese Premier Hua Guofeng and Indian Prime Minister Indira Gandhi met in } \\
\text { Belgrade at Yugoslavian President Tito's funeral. }\end{array}$ \\
\hline June 1981 & Chinese Foreign Minister Huang Hua visited India. \\
\hline November 1984 & Chinese Vice-Premier Yao Yilin attended Mrs. Gandhi's funeral. \\
\hline September 1985 & $\begin{array}{l}\text { Chinese Premier Zhao Ziyang and Indian Prime Minister Rajiv Gandhi met at the } \\
\text { UN. }\end{array}$ \\
\hline April 1987 & $\begin{array}{l}\text { Indian Defense Minister K.C. Pant made a stopover in Beijing on his way back } \\
\text { from Pyongyang. }\end{array}$ \\
\hline June 1987 & Indian Foreign Minister N.D. Tiwari visited China. \\
\hline December 1988 & Indian Prime Minister Rajiv Gandhi paid a historic visit to China. \\
\hline October 1989 & Chinese Vice-Premier Wu Xueqian visited India. \\
\hline March 1990 & Chinese Foreign Minister Qian Qichen visited India. \\
\hline May 1990 & Indian Deputy Prime Minister Devi Lal visited China. \\
\hline December 1991 & Chinese Premier Li Peng visited India. \\
\hline May 1992 & Indian President Ramaswamy Venkataraman visited China. \\
\hline July 1992 & Indian Defense Minister Sharad Pawar visited China. \\
\hline September 1993 & Indian Prime Minister Narasimha Rao visited China. \\
\hline November 1993 & $\begin{array}{l}\text { Chinese People's Political Consultative Conference Chairman Li Ruihuan visited } \\
\text { India. }\end{array}$ \\
\hline December 1993 & PLA Deputy Chief of the General Staff Lt. Gen. Xu Huizi visited India. \\
\hline June 1994 & $\begin{array}{l}\text { Chinese Minister of Foreign Trade and Economic Cooperation Madam Wu Yi } \\
\text { visited India. }\end{array}$ \\
\hline July 1994 & $\begin{array}{l}\text { Chinese Foreign Minister Qian Qichen visited India; } \\
\text { Indian Chief of Army Staff Gen. B.C. Joshi visited China. }\end{array}$ \\
\hline September 1994 & Chinese Defense Minister Gen. Chi Haotian visited India. \\
\hline October 1994 & Indian Vice-President K.R. Narayanan visited China. \\
\hline November 1995 & Chinese National People's Congress Chairman Qiao Shi visited India. \\
\hline December 1996 & Chinese President Jiang Zemin visited India. \\
\hline December 1997 & $\begin{array}{l}\text { Chinese Communist Party Politiburo Standing Committee member Wei Jianxing } \\
\text { visited India. }\end{array}$ \\
\hline April 1998 & PLA Chief of the General Staff Gen. Fu Quanyou visited India. \\
\hline April 14-16, 1999 & Indian Foreign Minister Jaswant Singh visited China. \\
\hline
\end{tabular}




\section{APPENDIX E: The Sino-Indian Border Talks, 1981-1987}

\begin{tabular}{|c|c|}
\hline Round & Major Developments \\
\hline $\begin{array}{l}1 \\
\text { Beijing } \\
\text { December } 10-14,1981\end{array}$ & $\begin{array}{l}\text { China proposed the so-called package deal and called for a } \\
\text { comprehensive settlement on the basis of the LAC; India insisted } \\
\text { on a sector-by-sector approach, with the Colombo proposals as the } \\
\text { basis for negotiating a settlement acceptable to both sides. }\end{array}$ \\
\hline $\begin{array}{l}2 \\
\text { New Delhi } \\
\text { May } 17-20,1982\end{array}$ & $\begin{array}{l}\text { China proposed the five principles; Indian proposal had six } \\
\text { principles. }\end{array}$ \\
\hline $\begin{array}{l}3 \\
\text { Beijing } \\
\text { January } 27-\text { February } 2,1983\end{array}$ & Both sides acknowledged continued differences. \\
\hline $\begin{array}{l}4 \\
\text { New Delhi } \\
\text { October } 24-30,1983\end{array}$ & $\begin{array}{l}\text { China accepted India's sector-by-sector approach. The two sides } \\
\text { also agreed to broaden the agenda to include trade, technical co- } \\
\text { operation, cultural and educational exchanges, and international } \\
\text { affairs of mutual interest. }\end{array}$ \\
\hline $\begin{array}{l}5 \\
\text { Beijing } \\
\text { September } 17-22,1984 \\
\end{array}$ & $\begin{array}{l}\text { China appeared to accept the McMahon Line in the eastern sector } \\
\text { with minor Indian concessions, with demands for some pieces of } \\
\text { Indian territory in the Aksai Chin area. }\end{array}$ \\
\hline $\begin{array}{l}6 \\
\text { New Delhi } \\
\text { November } 7-11,1985\end{array}$ & $\begin{array}{l}\text { China backtracked to the package deal position, focusing on the } \\
\text { eastern sector. India suggested again that the Colombo proposals } \\
\text { be the basis of negotiation. }\end{array}$ \\
\hline $\begin{array}{l}7 \\
\text { Beijing } \\
\text { July } 19-23,1986\end{array}$ & $\begin{array}{l}\text { Both sides hardened positions against the background of the } \\
\text { elevation of the NEFA to the statehood of Arunachal Pradesh and } \\
\text { the Sumdorong Chu Valley dispute. }\end{array}$ \\
\hline $\begin{array}{l}8 \\
\text { New Delhi } \\
\text { November } 14-17,1987\end{array}$ & $\begin{array}{l}\text { India gave up its "boundary settlement or nothing" stand and } \\
\text { stated that Rajiv Gandhi would visit China. China appreciated } \\
\text { India's position on Tibet. }\end{array}$ \\
\hline
\end{tabular}

Sources: Sumit Ganguly, "The Sino-Indian Border Talks, 1981-1989: A View from New Delhi," Asian Survey XXIX:12 (December 1989), pp. 1123-1135; Gopal Malviya, Sino-Indian Relations: Security Environment in Nineties (Madras: University of Madras, 1992), pp. 88-96. 


\section{APPENDIX F: Sino-Indian Joint Working Group (JWG) Meetings, 1989-1999}

\begin{tabular}{|c|c|}
\hline $\begin{array}{c}\text { JWG } \\
\text { Meeting/Timeframe }\end{array}$ & Major Developments \\
\hline $\begin{array}{l}1^{\text {st }} \text { JWG meeting } \\
\text { July } 1-4,1989 \text {, Beijing }\end{array}$ & $\begin{array}{l}\text { The two sides agreed that military experts would work out measures to } \\
\text { ensure "peace and tranquillity" along the LAC. }\end{array}$ \\
\hline $\begin{array}{l}2^{\text {nd }} \text { JWG meeting } \\
\text { August-September 1990, } \\
\text { New Delhi }\end{array}$ & $\begin{array}{l}\text { The two sides agreed that regular meetings in the border areas between the } \\
\text { military personnel should be established to expand contacts, especially the } \\
\text { respective sides' border guards. }\end{array}$ \\
\hline $\begin{array}{l}3^{\text {rd }} \text { JWG meeting } \\
\text { May } 13,1991, \text { Beijing }\end{array}$ & $\begin{array}{l}\text { No substantive progress, but the two sides further enhanced their } \\
\text { understanding of each other's positions and agreed to continue the process. }\end{array}$ \\
\hline $\begin{array}{l}4^{\text {th }} \text { JWG meeting } \\
\text { February } 20-21,1992 \\
\text { New Delhi }\end{array}$ & $\begin{array}{l}\text { Flag meetings between military personnel formally established, twice a year } \\
\text { (June and October) at the Bum La Pass in the eastern sector and the } \\
\text { Spanggur Gap in the western sector. In addition, it was also proposed that } \\
\text { direct telephone links between local commanders should be set up, as well } \\
\text { as exchanges of views on CBMs, including prior notification of military } \\
\text { exercises. }\end{array}$ \\
\hline $\begin{array}{l}5^{\text {th }} \text { JWG meeting } \\
\text { October } 27-29,1992, \\
\text { Beijing }\end{array}$ & $\begin{array}{l}\text { The two sides frankly exchanged views on the border issue and stated each } \\
\text { other's positions. }\end{array}$ \\
\hline $\begin{array}{l}6^{\text {th }} \text { JWG meeting } \\
\text { June } 25-30,1993 \\
\text { New Delhi }\end{array}$ & $\begin{array}{l}\text { Decided on a set of additional measures that would ensure greater } \\
\text { transparency in the location of forward posts and military activities along } \\
\text { the LAC, including prevention of air intrusion and redeployment of forces. }\end{array}$ \\
\hline $\begin{array}{l}7^{\text {th }} \text { JWG meeting } \\
\text { July } 1994 \text {, Beijing }\end{array}$ & $\begin{array}{l}\text { Failed to resolve the persistent differences between the two sides over ways } \\
\text { to reduce close encounters in some areas along the LAC. }\end{array}$ \\
\hline $\begin{array}{l}8^{\text {th }} \text { JWG meeting } \\
\text { August } 1995, \text { New Delhi }\end{array}$ & $\begin{array}{l}\text { Agreed to pull back troops from four forward posts some } 50-100 \text { yards from } \\
\text { each other. }\end{array}$ \\
\hline $\begin{array}{l}9^{\text {th }} \text { JWG meeting } \\
\text { October 1996, Beijing }\end{array}$ & $\begin{array}{l}\text { Two sides agreed to increase reciprocal visits by military personnel with the } \\
\text { rank of major general; to establish two additional meeting places along the } \\
\text { eastern section of the Sino-Indian border for military personnel manning the } \\
\text { disputed line of control. }\end{array}$ \\
\hline $\begin{array}{l}10^{\text {th }} \text { JWG meeting } \\
\text { August } 4-5,1997 \\
\text { New Delhi }\end{array}$ & $\begin{array}{l}\text { Clarification of LAC discussed and the two sides focused on implementing } \\
\text { the } 1993 \text { and } 1996 \text { CBM agreements. Also pledged to continue dialogue on } \\
\text { a mutually acceptable border. }\end{array}$ \\
\hline $\begin{array}{l}11^{\text {th }} \text { JWG meeting } \\
\text { April } 26-27,1999 \text {, } \\
\text { Beijing }\end{array}$ & $\begin{array}{l}\text { The meeting was originally scheduled for November } 1998 \text {. Because of the } \\
\text { Indian nuclear testing and the deterioration of bilateral relations, China } \\
\text { cancelled the meeting. The meeting was re-convened and both sides } \\
\text { pledged to restore bilateral relations and move the confidence-building } \\
\text { process forward. }\end{array}$ \\
\hline
\end{tabular}




\section{APPENDIX G: Selected Ground Sensors for Monitoring}

\section{Taut Wire Sensor}

\section{Overview}

Taut wire sensor technology has been in use for a number of years in a variety of applications. Taut wire sensors can be installed on an existing fence or can be freestanding. Its simple design and low nuisance alarm rate make the taut wire sensor a popular choice for a variety of treaty and nontreaty applications.

\section{Operational Concept}

The taut wire sensor operates on the premise that a steel wire with the appropriate properties will function as a spring over a wide temperature range. Several high-tensile-strength wires, usually barbed, are strung horizontally and tensioned between two anchor posts. A sensor post is located at approximately the midpoint of the wires. Each wire is connected to a sensor. Attempting to climb over the fence or to spread the wires displaces the sensor and causes an alarm. Cutting the wire displaces the sensor by the tension on the other side of the sensor post.

Several manufacturers produce taut wire sensors. Some models use a mechanical switch. Other models use piezoelectric devices or strain gauges. However, the principle of operation is the same for all taut wire sensors. Movement of the wire is monitored and reported when the wire is moved by more than a preset amount.

\section{Features} applications

A variety of features make the taut wire intrusion detection system attractive for security

The taut wire sensor

- is not disturbed by most environmental conditions.

- has one of the lowest nuisance alarm rates of all exterior sensors.

The taut wire sensor fence

- can follow minor terrain variations.

- acts a deterrent because of the barbed wire.

- acts as a barrier and defines the location of a border.

The cost of an 8 -foot taut wire fence with a 40 -inch outrigger is approximately $\$ 60 /$ foot $(\$ 200 / \mathrm{m})$.

\section{Applications}

The taut wire sensors are primarily used for perimeter and border applications. Environmental conditions normally do not cause false alarms; therefore, the taut wire sensor can be used successfully in harsh environments. It is important that the anchor and sensor posts be very stable. Although it is possible to mount the taut wire sensor on an existing fence, it is recommended that new posts be installed for the sensor and anchor post. 


\section{Monostatic Microwave Intrusion Detection Systems}

\section{Overview}

Microwave sensor technology has been in use for a number of years in a variety of applications. Microwave sensors can be classified as either monostatic or bistatic depending on the configuration of the antennas. Bistatic microwave sensors have separate transmit and receive antennas located at opposite ends of the detection zone. Monostatic microwave sensors locate the transmit and receive antennas together in a single housing. Microwave sensors can be quickly installed and made operational for a variety of applications.

\section{Operational Concept}

A monostatic microwave transmits a signal in the $\mathrm{X}$ or $\mathrm{K}$ frequency band. The receive antenna monitors reflections to obtain a "quiet" reference level when there is no activity in the detection zone. The detection zone is a teardrop shape that can be adjusted from close range to up to 400 feet. The width of the zone ranges from 3 to 24 feet depending on the settings. Intruders entering the zone cause a change in the received signal strength, which generates an alarm.

Monostatic microwave sensors are designed to detect stealthy intruders. The sensor also works very well at detecting vehicles and other large objects.

\section{Features}

The following features make the monostatic microwave intrusion detection system attractive for security applications:

- Easy to install

- Portable

- Low power (operates from batteries for several days at a time)

- Works well for monitoring portal areas

A monostatic microwave sensor capable of covering an area of approximately 400 feet to detect crawling intruders is approximately $\$ 2,000$.

\section{Applications}

The strength of the monostatic microwave sensor is that it can be rapidly deployed around an item or area. Although the sensor can be permanently mounted, its low power requirements and ease of setup make it ideal for non-fixed locations. The sensor can be set up quickly across roads and paths to detect people and vehicles.

\section{Active Infrared Intrusion Detection Systems Technology}

\section{Overview}

Active infrared sensor technology has been used for over 20 years to provide perimeter security at military installations, power plants, and correctional facilities. 
Active infrared sensors detect changes in the signal power of a line-of-sight infrared beam created between a transmitter and a receiver. The optical system consists of pole-mounted multiple transmitters and receivers on concrete bases (portable systems use tripods) at the two ends of the detection zone. These sensors can be either single- or multiple-beam systems.

\section{Operational Concept}

The active infrared transmitter transmits modulated pulses of infrared energy from the focal point of a transmitter lens to the focal point of a receiver lens. If this beam of energy is broken (for example, by an intruder), the signal strength monitored at the receiver lens is reduced and the sensor generates an alarm. The detection zone for a multiple-beam infrared sensor is basically a vertical plane. The effective height of this plane is determined by the number and position of the transmitter and receiver lenses. A typical perimeter detection zone is 100 meters long.

Active infrared sensors are designed to detect stealthy intruders; they also detect vehicles and other large objects.

\section{Features}

The following features make the active infrared intrusion detection system attractive for security applications:

- Good probability of detection if an intruder passes through the invisible beams

- Available in portable versions that use tripod supports

- Narrow detection zone that is advantageous for monitoring perimeter sectors that have restricted sensor zone width

\section{Technical Characteristics}

The IPID Rapid Deployment Intrusion Detection System (RDIDS) is one example of an active infrared system. The technical characteristics of this system are:

- Lens diameter: $88.9 \mathrm{~mm}$

- Pulse frequency: $1200 \mathrm{~Hz}$

- Power 120 Vac or 12 Vdc

- Current requirement: $200 \mathrm{~mA}$

- Operating temperature: $-30^{\circ} \mathrm{C}$ to $+60^{\circ} \mathrm{C}$

- Photovoltaic power option available

- Radio frequency (RF) option available

\section{Cost}

An active infrared sensor capable of covering a zone of approximately 100 meters to detect crawling, running or walking intruders is approximately $\$ 10,000$. The RDDS with the photovoltaic power option and the $\mathrm{RF}$ alarm link option is approximately $\$ 16,500$. 


\section{Applications}

An active infrared sensor provides a continuous field of infrared energy. Although the sensor can be permanently mounted, a portable system mounted on tripods is easily set up at temporary locations. The portable sensor can be set up quickly across roads and paths and around the perimeter of a facility to detect people and vehicles.

\section{Bistatic Microwave Intrusion Detection Systems Overview}

Microwave sensor technology has been in use for over 20 years to provide perimeter security at military installations, power plants, and correctional facilities by generating an invisible zone for perimeter protection.

Microwave sensors are classified as either monostatic or bistatic depending on the antenna configuration. In monostatic microwave sensors, the transmit and receive antennas are located in a single housing. Bistatic microwave sensors use separate transmit and receive antennas located at opposite ends of the detection zone. Microwave sensors can be installed quickly and easily for a variety of applications.

\section{Operational Concept}

A bistatic microwave transmitter transmits a signal in the $\mathrm{X}$ or $\mathrm{K}$ frequency band. The dynamic target multipath signal is monitored by the receive antenna to obtain a quiet reference level when there is no activity in the detection zone. The cigar-shaped detection zone typically is 6 to 12 meters wide, depending on the distance between the transmit and receive antennas, and has a range of up to 200 meters. Intruders entering the protected zone cause a change in the received signal strength or phase, which generates an alarm.

Bistatic microwave sensors are designed to detect stealthy intruders but also detect vehicles and other large objects.

\section{Features}

The following features make the bistatic microwave intrusion detection system attractive for security applications:

- Easy to install

- Portable versions available

- Low power requirements (can operate from batteries for several days at a time)

- Well suited for perimeter monitoring

\section{Technical Characteristics}

The RACON Intrusion Detection System (RIDS) Model 16000 is an example of a bistatic microwave sensor. This system has the following technical characteristics:

- Power requirements: 11 to $15 \mathrm{Vdc}$

- Carrier frequency: $10.525 \mathrm{GHz}$ 
- Operating temperature: $-40^{\circ} \mathrm{C}$ to $+70^{\circ} \mathrm{C}$

- Power consumption: $100 \mathrm{~mA}$

- Built-in test meter available

- Multipath sidetone generator and speaker available

- Radio frequency (RF) alarm link option available

Cost

A bistatic microwave sensor capable of covering a zone of approximately 100 meters to detect crawling intruders is approximately $\$ 3,000$. The RIDS 16000 Bistatic Microwave sensor with built-in test meter, multipath side-tone generator, and speaker is approximately $\$ 3600$. Without the built-in test meter, multipath generator, and speaker, the cost is approximately $\$ 2700$.

\section{Applications}

A bistatic microwave sensor provides a continuous field of microwave energy. Although the sensor can be permanently mounted, its low power requirements and ease of set-up make it ideal for temporary locations such as perimeters, chokepoints, and border areas. The sensor can be set up quickly across roads and paths to detect people and vehicles.

\section{Fiber Optic Intrusion Detection Systems Overview}

Fiber optic technology can provide a feasible solution for some security problems. Lightweight and easy to install, fiber optic sensors can be added to existing fencing or buried in the ground.

\section{Operational Concept}

When an optical fiber is disturbed, the disturbance changes the way the fiber conducts light. Although the change is very small, with the right light source and detection method, this change can be amplified to create a useful signal similar to the voltage generated by a microphone in contact with a moving or vibrating object.

On the simplest level, a laser injects coherent light (light for which all of its components consistently rise and fall together) into the fiber. This light transverses the fiber to a detector, where it is converted to an electrical signal. The signal from the detector is processed to decide whether there is a disturbance of the right quality to generate an alarm. This signal processing is based on parameters set by the user to control the type of signal that will cause an alarm.

\section{Features}

The following features make the fiber optic intrusion detection system attractive for security applications:

- The fiber optic cable is undisturbed by lightning or high-voltage environments.

- Ground installations can be used to detect people or vehicles. 
- Ground installations offer the unique advantage of being out of sight and out of the path of many sources of nuisance alarms.

- Some fiber optic sensors have many processing parameters to provide a high level of signal discrimination.

\section{Cost}

Fiber optic systems are relatively inexpensive as follows:

- A distributed monitoring system for buried, fence, or interior applications, mounted in a National Electrical Manufacturers Association enclosure with tamper switch costs approximately $\$ 2,400$ per single unit puchase.

- Rugged sensing cable for direct burial costs approximately $\$ 2.45$ per meter.

- Sensing cable for use in conduit or interior applications costs approximately $\$ 2.15$ per meter.

\section{Applications}

The fiber optic sensor can be used on fences directly (if the fence is well constructed) or in conduit if high winds are a potential problem. The fiber optic sensor can be installed in gravel for people and vehicle detection or, if only vehicles need to be detected, under other media such as soil or paved roads. The fiber optic sensor also can be installed on roofs, in walls, or in the ceilings of buildings. 


\section{About the Authors}

Dr. Waheguru Pal Singh Sidhu is a specialist on South Asian security. He is the principal author of the "Special Feature on Asian Nuclear Testing" in the July 1998 issue of Jane's Intelligence Review and has written on "A Virtual Nuclear De-alert in South Asia" for the UNIDIR Newsletter Issue 38, "Nuclear De-alerting: Taking a Step Back", August 1998. He is also the author of Adelphi Paper 313: "Enhancing Indo-US Strategic Cooperation". He was the 1997-98 Warren Weaver Fellow for International Security at the Rockefeller Foundation and a Research Associate with the International Institute for Strategic Studies (IISS), London, in 199798. He was awarded his Ph.D. from the University of Cambridge, England, in July 1997 for his thesis on "The Development of an Indian Nuclear Doctrine Since 1980."

Dr. Jing-Dong Yuan is a Research Associate at the Institute of International Relations, University of British Columbia (UBC). Prior to his stint at the CMC as a Visiting Research Scholar, he was a Killam Postdoctoral Fellow at UBC and a Department of National Defence (Canada) Postdoctoral Fellow at York University, working in the areas of Asia Pacific security, arms control and nonproliferation, and Chinese defense and foreign policy. Dr. Yuan's recent publications have appeared in Contemporary Security Policy and the Journal of East Asian Affairs, among others. He has a Master's degree in international affairs from Carleton University and a Ph.D. in political science from Queen's University. He is working currently at the Center for Nonproliferation Studies, the Monterey Institute of International Studies. 
Cooperative Monitoring for Confidence-Building:

A Case Study of the Sino-Indian Border Areas

\section{Distribution}

350 MS 1373 CMC Library, 5341

1 MS 9018 Central Tech Files, 8940-2

2 MS 0899 Technical Library, 4916

1 MS 0612 Review \& Approval Desk, 4912 